\title{
Why Hire a Big 4 Auditor 500 Miles Away?
}

\author{
Lily Brooks ${ }^{1} \&$ Michael D. Yu ${ }^{2}$ \\ ${ }^{1}$ Department of Accounting, Washington State University, Pullman, USA \\ 2 Department of Accounting and Finance, University of West Georgia, Carrollton, USA \\ Correspondence: Michael D. Yu, Department of Accounting and Finance, University of West Georgia, Carrollton, GA \\ 30118-3010, USA. Tel: 1-678-839-6517.
}

Received: August 30, 2016

Accepted: September 15, 2016

Online Published: October 8, 2016

doi:10.5430/ijfr.v7n5p19

URL: http://dx.doi.org/10.5430/ijfr.v7n5p19

\begin{abstract}
This paper investigates why a firm would hire an auditor far away from its corporate headquarter. Using a sample from the Audit Analytics database, we show that $75 \%$ of the firms hire a Big 4 auditor less than 33 miles away from their headquarters, and the median distance is only 14 miles. For the majority of firms, the driving time from a client's headquarter to its auditor's office is less than 45 minutes, and the median driving time is only 21 minutes. However, our results also show that some firms are willing to go the extra mile and hire a remote auditor. About $10 \%$ of the sample hire a Big 4 auditor more than 150 miles away, and some firms even hire an auditor more than 500 miles away. We test a few possible explanations, including earnings management hypothesis, competitive audit fee hypothesis, diversified operating location hypothesis, etc. Our analysis shows that firms having the tendency to manage earnings are more likely to hire a remote auditor. Specifically, we find that firms that are more likely to report small positive earnings, more likely to have financial restatements, and more likely to report higher expected discretionary accruals, tend to hire remote auditors. We also find that firms with diversified geographic segments, not operating segments, are more likely to hire remote auditors. Finally, we show that competitive audit pricing affects firms' office choice, but only within certain distance. Beyond certain limit, there is no difference in audit fees offered by local and non-local auditors.
\end{abstract}

Keywords: geographic distance, auditor choice, office-level analysis, corporate governance, restatement

\section{Introduction}

This study analyzes why a firm would hire a Big 4 auditor far away from the firm's corporate headquarter. Increase in distance will likely increase transportation costs and the time and effort spent by both the auditor and the client to personally interact with each other. It may also increase the auditor's monitoring costs. We explore a few possible explanations, including earnings management, competitive audit pricing, close to accounting operations, auditor business risk management, and personal ties. Our empirical results are consistent with the earnings management story: Firms that are more likely to manage earnings tend to hire a remote auditor. We further find that firms more like to have financial restatements tend to hire a remote auditor more than 500 miles away. Our results also show that geographically diversified companies are more likely to choose a remote auditor. Finally, we find that competitive audit pricing affects clients' auditor choice, but only within certain distance. When the distance is beyond 150 miles, there is no difference in audit pricing between local and remote auditors.

Our paper is the first study that investigates the distance between Big 4 auditor offices and their clients' corporate headquarters across the 49 states. (Note 1) Specifically, we use Google Map to estimate the driving distance and time from a firm's corporate headquarter to its auditor's office. We find that $75 \%$ of the firms hire Big 4 auditors less than 33 miles from their corporate headquarters, and the median driving distance is only 14 miles. For the majority of firms (75\%), the driving time from a firm's headquarter to its auditor's office is less than 45 minutes, and the median driving time is only 21 minutes. We also estimate the distance from a firm's corporate headquarter to the closest Big 4 auditor office. We find that $90 \%$ of the firms could find a Big 4 office within 35 miles, and $98 \%$ of the firms could find a Big 4 office within 100 miles. Giving the advances in computing and communication technologies and the growing use of information network, we are surprised to see that Big 4 auditors are located so close to their potential clients. Together, these findings have a number of important implications.

First, results indicate that geographical proximity is important in the auditor-client relationship. However, the existing literature does not provide any explanations to this phenomenon. One possible explanation is that monitoring costs are 
sensitive to distance. When distance increases, the costs of physical monitoring are likely to be prohibitive. So auditors have the incentive to get geographically close to their potential clients. Another possible explanation is competition for clients. In order to compete for clients, auditors probably have to have a local presence. But results also show that $71 \%$ of the companies do not hire the closest auditor, and about $5 \%$ of the firms do not hire the closest office even if that office is from the same accounting firm as the remote office hired by these firms. These results indicate that there are other factors affecting firms' Big 4 office choice. Analyzing these determinants is essential for understanding the audit market. Second, results may indicate that competitions among accounting firms are extremely intense and that Big 4 auditors' expanding through practicing offices has reached the limit. It is hard to imagine that Big 4 offices are already located within 100 miles to $98 \%$ of the total population of corporations. The rest $2 \%$ of firms are generally located in remote rural areas. In order to continue growing, Big 4 auditors may have to explore other possibilities. Finally, results raise the question why some firms would avoid local Big 4 offices and choose an office far away from their corporate headquarters.

A few recent studies examine how the distance between auditors and clients affects audit quality. Jensen et al. (2008) find that the absolute value of abnormal accruals increases when the distance from a firm's corporate headquarter to its auditor's office increases. Choi et al. (2012) show that local auditors are negatively associated with the absolute value of discretionary accruals and accruals quality measures. Both studies argue that local auditors have information advantage, and hence provide higher quality audit. Our study is different from these studies in the following ways. First, we use different methods to estimate distance. Our study uses Google Map to precisely estimate the driving distance from a firm's corporate headquarter to its auditor's office, while these prior studies either use the metropolitan statistical area (MSA) to identify local and non-local auditors or use the latitude and longitude information to calculate the geographic distance between the center of the city where a client's headquarter is located and the center of the city where its auditor's office is located. (Note 2) These estimates inevitably contain big estimation errors and noise. Second, we use different samples to test hypothesis. Our study only uses Big 4 clients to test our hypothesis, while these prior studies combine both Big 4 and non-Big 4 clients in one sample, and use a Big 4 dummy to control for the Big 4 effect. However, as studies argue that firms self-select into Big 4 and non-Big 4 auditors and Big 4 clients are fundamentally different from Non-Big 4 clients (Copley et al., 1995; Abbott and Parker, 2000; Shu, 2000; Ireland and Lennox, 2002; Chaney et al., 2004), it is justified to believe that slope coefficients are different across these two groups of firms. Using a dummy variable to control for the Big 4 effect is probably not enough. Third, we address different research questions. Our study analyzes why firms would choose remote auditors, while these prior studies analyze how distance affects audit quality. Even if we believe that distance does decrease audit quality, it still begs the question why clients would hire remote auditors. Ultimately, it is the client that decides which auditor to hire. In any event, the existing empirical work does not examine some significant aspects of the distance between clients' corporate headquarters and auditor offices on which this paper focuses. Whereas prior work has taken office choice decisions as given, we seek to investigate the determinants of these decisions.

Our study makes several contributions to the literature. First, we precisely document the distance from a firm's corporate headquarter to its Big 4 auditor office, and the distance from a firm's headquarter to the closest Big 4 office. The findings that firms hire Big 4 auditors located so close to their corporate headquarters and Big 4 auditors are geographically located so close to their potential clients, to the best of our knowledge, are new. We believe that these measures are important in that they help us understand the national audit market of Big 4 auditors and competitions among these accounting firms. Second, Francis and Yu (2009) and Francis et al. (2012) find that audit quality is not homogeneous across Big 4 auditor offices and small offices tend to provide lower quality audit. However, these studies do not provide any explanations why Big 4 auditors would keep those small offices. The findings in this study may provide some clues to this question. If Big 4 auditors have to stay geographically so close to their clients, then they inevitably have to keep those small offices. Third, very little is known about firms' office choice among Big 4 auditors. To the best of our knowledge, this is the first study that addresses this question. Prior studies generally combine big 4 and Non-Big 4 clients in one sample and analyze firms' auditor choice between Big 4 and non-Big 4 accounting firms. (Note 3)

Finally, our results show that firms having the intention to manage earnings tend to hire remote auditors. This finding raises the question whether it is legitimate for a firm to hire an auditor far away from its corporate headquarter. To the extent that financial reporting quality has already been affected, we believe that it is justified to put some restrictions on firms' office choice. However, this question has not been addressed by the profession and policy makers.

The remainder of the paper proceeds as follows. The next section explores several possible explanations why a company would hire a Big 4 auditor far away from its headquarter. Section 3 addresses model specification and 
research design issues. Empirical tests are reported in section 4. Implications of the study are discussed in the concluding section.

\section{Hypothesis Development}

Studies show that some firms hire their primary auditors far away from their corporate headquarters (Jensen et al., 2008; Choi et al. 2012). Intuitively, increase in the distance from a client's headquarter to its auditor's office will increase the auditor's physical monitoring costs, and also increase the time and effort spent by both the auditor and the client to personally interact with each other (Degryse and Ongena, 2005; John et al., 2011; Ayers et al. 2011). Behavior-based explanation also suggests that firms should select a local auditor they are more likely to be familiar with (Merton, 1987; Heath and Tversky, 1991; Huberman 2001). Why would these firms be willing to go the extra mile? Below we discuss a few possible explanations: (1) the earnings management hypothesis, (2) the competitive audit pricing hypothesis, and (3) other possible explanations, including diversified operating locations, personal connections, and the possibility that there are no nearby Big 4 auditors or local Big 4 auditors are unwilling to accept the client.

\subsection{The Earnings Management Hypothesis}

The first possible explanation is that firms having the intention to manage earnings are more likely to hire remote auditors. Our conjecture is based on three arguments in the literature. First, studies argue that distance increases information asymmetry and investors investing in their local businesses have an information advantage. (Note 4) Coval and Moskowitz (1999, 2001) and Hau (2001) find that investment managers exhibit a strong preference for locally headquartered firms and earn substantial abnormal returns in nearby investments. They argue that fund managers are exploiting informational advantages in their selections of nearby stocks. Ivković and Weisbenner (2005) find similar results for individual investors. Similarly, using a large sample of analyst forecasts, Malloy (2005) finds that analysts issue more accurate earnings forecasts for local firms than for distant firms. He argues that local analysts possess an information advantage over other analysts, and this advantage translates into better performance.

These studies also provide possible explanations to this information advantage. They argue that local investors have better access to information than remote investors because they have daily exposure to local news stories, firsthand knowledge of the local economy, and personal connections with the local business community. They could also obtain valuable private information through informal talks with management, employees, and customers.

They can more readily visit the company and directly observe its operations. Local investors also spend less time collecting information since they are on-the-spot. These studies also argue that monitoring costs are substantial, and are likely to increase with the distance, because monitoring remote firms usually requires increased communication and transportation costs.

Second, studies also argue that distance affects the frequency of on-site visit. Lerner (1995) finds that venture capital organizations with offices less than five miles from a firm's headquarters are twice as likely to provide board members to the firm as those more than 500 miles away. He argues that the large monitoring costs associated with frequent visits to the firm and intensive involvement in the firm's operation discourage more remote venture capitalists from actively participating in governance activities in the firm. Petersen and Rajan (2002) find that the frequency with which a firm has to physically interact with a client determines how close the distance should be between the two parties. They find that the distance between the client and a bank is closer if the client has the need to visit the lender on a more frequent basis.

Finally, studies argue that distance affects corporate governance. Gaspar and Massa (2007) show that increases in local ownership are associated with increased monitoring, and locally held firms exhibit a higher quality of corporate governance. Kang and Kim (2008) find that local acquirers are more likely to have their representatives on the target's board and to replace poorly performing target management. Information advantage provides local investors with strong incentives to actively monitor target managers. To the extent that investors' monitoring costs increase with physical distance because of extra communication and transportation costs, they argue that monitoring costs are an important determinant of governance activities.

Based on the above studies, we conjecture that firms that intend to manage earnings are more likely to hire a distant auditor. Auditors have the responsibility to continuously monitor clients' financial reporting, and physical monitoring is more difficult across greater distances. A distant auditor is less likely to have private information regarding the firm's management, business risks, and earnings management incentives. It is also less likely for the engagement partner and senior manager to make frequent visits to the audit site and interact with the management, employees, and customers on a regular basis. The empirical evidence in the accounting literature is also consistent with this conjecture. Studies show that managers are less likely to use financial reporting discretion to manage earnings in the presence of 
local monitoring institutions (Ayers et al., 2011), and firms close to the monitoring institutions (such as SEC) are less likely to restate their financial statements (Kedia and Rajgopal, 2011), and more likely to issue going concern audit opinions (DeFond et al., 2008).

It is possible that a client choose a remote auditor because of personal connections. If personal ties are so important and both the client and the auditor are willing to go the extra mile, then it is possible that auditor independence will be compromised, and the client is more likely to manage earnings, ceteris paribus. In a similar context, Lennox (2005a) shows that affiliated companies are more likely than unaffiliated companies to receive clean audit opinions. He argues that affiliations impair audit quality by reducing the likelihood of problem discovery and the likelihood of reporting a discovered problem. So the personal connection explanation is consistent with our earnings management hypothesis discussed above.

\subsection{The Competitive Audit Pricing Hypothesis}

The second possible factor that might lead some firms to hire a distant auditor is the low audit fees offered by remote auditors during the competitive bidding process. It is well recognized in the literature that auditors would cut audit fees in order to obtain clients. Studies argue that auditors could even set audit fees below total costs in the initial period and recover their losses in later years (DeAngelo, 1981). The empirical evidence also shows that price cutting could be of a substantial amount and could persist over several years (Simon and Francis, 1988). However, local auditors could also cut audit fees in the initial period. So it is not clear how distant auditors could offer more competitive price than local auditors.

In a competitive audit market, audit fees are set to recover the auditor's costs plus a normal profit. Studies argue that audit fees are determined by actual labor usage and the rate per hour (Bell et al., 2008). When the distance between the auditor and the client increases, it is likely that the auditor's labor hour and audit costs, including transportation costs and costs of gathering audit information, will also increase. Ceteris paribus, we would expect distant auditors to charge higher audit fees. If a distant auditor wants to offer more competitive price, the only possible way is to cut hourly rate, assuming that audit effort will not be affected. In a competitive labor market, however, there are limits to the hourly rate that an accounting firm can adjust.

Even if the auditor succeeds in obtaining a distant client by offering substantially lower initial rate than local auditors, it must make profit in future periods. Studies do find that auditors charge lower fees in the first three years of audit engagement, but increase to normal level after that (Simon and Francis, 1988). However, it is also reported in the literature that audit firms sometimes may not just offer competitive initial prices, but also make bids with fees guaranteed for several years, and give clients the option to renegotiate prices after receipt of competitive offers (DeAngelo, 1981). If a local auditors offer such terms to the clients, it would be impossible for distant auditors to offer more competitive prices and at the same time make profit.

It is possible that a distant auditor could lower its audit effort in order to lower its costs after making a successful competitive bid. In doing so, however, the auditor jeopardizes its reputation and may even face litigation risk. It is also possible for remote non-Big 4 auditors to provide lower audit fees than local Big 4 auditors, as studies show that Big 4 auditor charge audit fee premium. But this should not be an issue in this study as our sample is restricted to Big 4 auditor clients only. Furthermore, it does not make sense for a remote Big 4 office to compete with a local Big 4 office from the same accounting firm. There should be policies within each firm to prevent individual offices from competing with each other. Finally, Jensen et al. (2008) find that audit fees are positively associated with distant auditors, even though their sample includes both Big 4 and non-Big 4 clients. How audit fees affect clients' Big 4 office choice is still an empirical question.

\subsection{Other Possible Explanations}

The third possible explanation is that a client chooses a remote auditor because its primary accounting operations are geographically close to that auditor office. It is possible that a firm's accounting operations are located far away from its corporate headquarter, especially for Big 4 auditor clients which are generally large public corporations and have branches and subsidiaries across the country and around the world. However, a company's primary accounting office is generally located close to its corporate headquarter (if not in the same building). Even if its primary accounting operations are not in the same city, it still makes sense to hire a local Big 4 auditor which will then coordinate the audit work through the auditor's offices across the country. It would be much more convenient for the VP in charge of finance and accounting to interact with a local auditor's engagement partner than someone from 500 miles away. In any event, the testable prediction is that firms with more geographically diversified operations are more likely to hire remote auditors. 
Another possible explanation is that these clients cannot find a local Big 4 auditor because of their poor financial position and performance. Studies show that Big 4 auditors have incentives to screen out risky clients in order to avoid litigation risk and protect their own brand name reputation (Francis and Krishnan, 2002; Johnstone and Bedard, 2003). However, this explanation is also problematic. If a remote Big 4 auditor could accept this client, then why could not a local Big 4 auditor accept it? A related argument would be that there are no Big 4 auditors in the area where these firms' headquarters are located. If a company is located in a remote rural area, it is possible that there are no local Big 4 auditors. In the data analysis section, we will control for this possible factor. Finally, according to the survey reported by Jensen et al. (2008), some firms also choose a remote auditor because there are no local specialist auditors. In our multivariate analysis, we also test for industry specialist auditors.

\section{Research Design}

\subsection{Model Specification}

To examine the factors that affect firms' decision to choose a remote auditor, we estimate the following model:

$$
\text { DISTANCE }=\lambda_{0}+\lambda_{1} \text { TESTING_VARIABLES }+\mathbf{X}^{\prime} \boldsymbol{\lambda}+\ddot{v}
$$

where DISTANCE is the driving distance from a company's headquarter to its auditor's office. As the distribution of distance is heavily skewed and the economic impact of distance is likely nonlinear (Petersen and Rajan, 2002), we create a few refinements based on this raw measure of distance, and use these refined measures as the dependent variable in the multivariate analysis. First, we create a log-transformed measure of distance. When this continuous measure is used as the dependent variable, we use OLS to estimate this equation with White (1980) robust standard errors to control for heteroscedasticity. As in Lennox (2005b) and Francis and Yu (2009), two-digit SIC codes are also included to control for industry fixed effects. In addition, we also include state dummies to control for potential state fixed effects. As an alternative, we also create three dummy variables. The first one is coded as 1 if a firm hires a remote auditor more than 150 miles away and 0 otherwise. The second dummy is coded as 1 if a firm hires a remote auditor more than 300 miles away and 0 otherwise, and the third dummy is coded as 1 if a firm hires a remote auditor more than 500 miles away and 0 otherwise. Following Gould et al. (2006), we use MLE to estimate a probit model with robust standard errors when these dummy variables are used as the dependent variable. Two-digit SIC code dummies and state dummies are also included.

Following prior studies, we use three measures to test the earnings management hypothesis. The first measure is the performance adjusted abnormal accruals. We use the absolute value of abnormal accruals as the testing variable (ABSACCR), and predict a positive association with the dependent variable. (Note 5) The second measure is based on Burgstahler and Dichev (1997) and DeGeorge et al. (1999). These studies argue that firms reporting small positive profits (avoiding losses) are more likely to manage earnings. We create a dummy variable, DISCON, that takes the value of 1 if a firm reports small positive earnings and 0 otherwise, and predict a positive sign on this variable. Our third measure of earnings management is accounting restatement. Restatements indicate that the originally issued financial statements violated GAAP and is of low quality (Palmrose and Scholz, 2004; Kinney et al., 2004). Ceteris Paribus, restatement firms are more likely those firms that managed earnings. We create a dummy variable, RESTATE, that takes the value of 1 if a firm restated its financial statements and 0 otherwise, and again predict a positive coefficient on this variable.

We use the log-transformed audit fees (AUDIT) to test the hypothesis that clients hire remote auditors because of competitive audit fees, and predict a negative sign on this coefficient. We construct two variables to test the diversified operating location hypothesis: the number of operating segments (OPSEG) and the number of geographic segments (GESEG). (Note 6) We predict positive coefficients on these two variables. Finally, following the literature (Francis et al., 2005; Francis and Yu, 2009), we use proxies of national industry specialist (NSPECIALIST) and city industry specialist (CSPECIALIST) to test the explanation that clients hire a remote auditor because there are no local specialist auditors. NSPECIALIST is a dummy variable that takes the value of 1 if an auditor is the number one auditor in an industry in terms of aggregated client audit fees in a specific fiscal year and 0 otherwise. CSPECIALIST is a dummy variable that takes the value of 1 if an office is the number one auditor in terms of aggregated client audit fees in an industry within that city in a specific fiscal year and 0 otherwise. We predict positive coefficients on both these two variables.

There are no prior studies that specifically examine clients' office choice among Big 4 auditors. For control variables, we borrow from the literature that analyzes clients' auditor choice between Big 4 and non-Big 4 auditors. Following prior studies, especially Johnson and Lys (1990), Francis et al. (1999), and Choi and Wong (2007), we include the following firm characteristics in the model: firm size (SIZE), operating cycle (CYCLE), capital intensity (CAPITAL), 
and new issue of securities (ISSUE). SIZE is the natural log of total assets. Operating cycle (CYCLE) is calculated as the sum of days' inventory and days' accounts receivable divided by 30 , where days' inventory is calculated as 365 times the average of the beginning and ending inventory divided by the cost of goods sold, and days' accounts receivable is calculated as 365 times the average of the beginning and ending accounts receivable divided by sales. Capital intensity (CAPITAL) is the ratio of gross property, plant, and equipment to total assets. New issue of securities (ISSUE) is a dummy variable that takes the value of 1 if a firm issues equity or debt securities during the year. (Note 7)

Simunic and Stein (1987) find that a client's cash flow affects its auditor choice. Following this study, we include the net cash flow from operating activities (CFO) in the model. CFO is defined as the difference between net income (COMPUSTAT data172) and total accruals, which is derived from balance sheet accounts. As in Chaney et al. (2004) and Fortin and Pittman (2007), we include quick ratio, the number of employees, asset turnover, and foreign sales as additional controls. Quick ratio (QUICK) is the ratio of the sum of cash and marketable securities to total assets. The number of employees (EMPLOYEE) is the number of employees in millions. Asset turnover (TURNOVER) is the ratio of sales to total assets. Foreign sales (FOREIGN) is a dummy variable that takes the value of 1 if a firm reports foreign sales, and 0 otherwise. We also include a measure of R\&D intensity (R\&D), defined as the total R\&D expense deflated by total assets, as studies show that this measure is associated with firms' auditor choices (Godfrey and Hamilton, 2005; Wang et al., 2008).

Copley and Douthett (2002) and Weber and Willenborg (2003) find that risk factors are associated with auditor choice. Following these studies, we construct two risk measures: Altman (1968) Z-score (ZSCORE) and standard deviation of revenues (STDREV). (Note 8) We use a rolling window up to 10 periods to estimate the standard deviation of revenues. Finally, following Francis et al. (1999) and Guedhami et al. (2009), we also add the following changes in firm characteristics: change in receivables (CHREC) and change in earnings (CHEARN). Both of these two measures are deflated by total assets (Note 9)

\subsection{Sample Selection}

The sample includes all firms in fiscal year 2005. Auditor location information, financial restatement, and audit fees are from Audit Analytics. Financial statement information and the street address of firms' headquarters are from COMPUSTAT. We start with all publicly traded firms that are located in the United States and have headquarters location information at the end of 2005. (Note 10) We first extract the information about auditor location (city and state where an auditor is located) from Audit Analytics' audit opinion file. Observations without auditor location information and those whose auditors are not located in the United States are excluded. After merging this dataset with the audit fee file and restrict the sample to clients audited by Big 4 auditors only, there are 8,385 observations at the end of fiscal year 2005. We next merge this dataset with COMPUSTAT's name and address file, and exclude firms that only have PO BOX address but do not have street address. (Note 11) Following the literature, especially Coval and Moskowitz (1999) and Malloy (2005), we exclude firms headquartered in Hawaii or Alaska, as these firms are geographically isolated from the outside audit market. (Note 12) We lose a few dozens of observations when estimating the driving distance using Google Map. (Note 13) So after the above steps, our initial sample consists of 4,378 observations that have the required headquarter location and auditor location information and their driving distance could be estimated through Google Map.

In order to test our hypotheses, we next merge this initial sample with the COMPUSTAT annual industrial file. We exclude observations with missing values on total assets, sales revenue, and the number of employees. In addition, the financial sector (SIC codes $60-69$ ) and regulated industries (SIC codes $44-49$ ) are excluded because their accruals structure is qualitatively different. Furthermore, we exclude industries with less than 10 observations in order to estimate discretionary accruals by industry. The final sample includes 3,588 unique companies audited by Big 4 auditors in fiscal year 2005.

\subsection{Geographic Distance}

We use Google Map to estimate the driving distance from a client's corporate headquarter to its lead auditor's office. This method is similar to the one employed by Agarwal and Hauswald (2010), which uses Yahoo! Maps and Yahoo's Smart View to measure distance, and identical to the one used by DeFond et al. (2008), which also uses Google map to estimate distances.

As we mentioned earlier, we obtain the street address of a company's headquarter location from COMPUSTAT, and we extract auditor's office location from Audit Analytics. Audit Analytics only provides information about the city and state in which an auditor office is located, but does not provide its street address. We obtain a Big 4 office's street address from the auditor's website. There are currently 312 Big 4 offices according to their websites. However, some 
Big 4 offices identified through Audit Analytics are not listed on the auditor's website. We find that there are several reasons for this discrepancy. First, auditors may move their offices to a nearby location. For example, KPMG moved its Costa Mesa (California) office to Irvine in Feb 2009. Ernst \& Young moved its Woodland Hills (California) office to Westlake Village in Oct 2008. Second, some Big 4 offices may also be closed due to different business reasons. For example, PWC closed its Memphis (Tennessee) office on May 31, 2007, and eliminated 59 jobs. Deloitte also closed its Hickory (North Carolina) office a few years ago. Whenever an office's street address is not available on the auditor's website, we search the internet and locate the historical street address for that office. For reasons discussed earlier, we exclude auditor offices located in Alaska and Hawaii. Overall, we have identified street addresses for 282 unique Big 4 offices in our initial sample. (Note 14)

The most common method in the literature, however, is to use the Haversine formula to calculate distance. (Note 15) These distance estimates are straight line distances. Even though there are instances where the straight line and driving distances are close, but that is not the usual case. Nevertheless, as a sensitivity analysis, we also use the Vincenty formula to calculate the geodesic distances between zip code centroids for any two zip codes. The Vincenty formula, which estimates distance using a pair of latitude/longitude points on the earth's surface, is more accurate than the most commonly used Haversine formula. (Note 16) Finally, in order to find the distance from a client's corporate headquarter to the closest Big 4 office, we estimate the driving distances from each firm's corporate headquarter to all 282 unique Big 4 offices across the continent. This method helps us precisely locate the closest Big 4 office regardless of whether this office is located in the same Metropolitan Statistical Area (MSA) or in a nearby city/state. (Note 17)

\section{Empirical Results}

\subsection{Descriptive Statistics}

Table 1 reports the summary statistics for the estimated distances between clients' corporate headquarters and Big 4 auditors' offices. The first three measures are estimated distance from a firm's corporate headquarter to its lead auditor's office. Surprisingly, $75 \%$ of the firms hire auditors only less than 33 miles away, and the median driving distance is only about 14 miles. The driving time between a client's headquarter to its auditor's office is less than 43 minutes for the majority of firms, and the median driving time is only 21 minutes. Furthermore, results show that the median straight-line (geodesic) distance is only about 11 miles, and $90 \%$ of firms are located less than 111 miles from their auditors. Table 1 also shows that about $10 \%$ of the sample hire an auditor more than 150 miles away, and the driving time is more than 145 minutes. $5 \%$ of the companies are even willing to hire an auditor more than 340 miles away, and the driving time is over 6 hours. (Note 18)

Table 1. Distance between clients' headquarters and Big 4 auditor offices

\begin{tabular}{|c|c|c|c|c|c|c|c|c|c|c|c|c|c|}
\hline Distance Measures & Mean & Std & Min & \multicolumn{9}{|c|}{ Percentile } & Max \\
\hline Driving Distance (miles by car) & 85 & 307 & 0.1 & 0.5 & 3.7 & 13.9 & 32.5 & 41.7 & 70.9 & 149 & 340 & 1,032 & 3,095 \\
\hline Driving Time (minutes by car) & 90 & 298 & 0 & 2 & 10 & 21 & 43 & 52 & 77 & 145 & 361 & 1,008 & 3,000 \\
\hline Geodesic Distance (miles) & 71 & 264 & 0 & 0 & 3 & 10.9 & 25.5 & 33.6 & 55.3 & 111 & 291 & 851 & 2,698 \\
\hline Driving Distance to the Closest Auditor(miles by car) & 17 & 33 & 0.1 & 0.2 & 0.9 & 8.2 & 18.3 & 21.4 & 26.5 & 34.7 & 71 & 115 & 441 \\
\hline Geodesic Distance to the Closest Auditor (miles) & 14 & 28 & 0 & 0 & 0.7 & 7 & 15 & 18.4 & 23 & 28.9 & 59 & 101 & 380 \\
\hline
\end{tabular}

This table reports summary statistics for the distance between clients' corporate headquarters and Big 4 auditors' offices. The sample contains 4,378 observations for fiscal year 2005 and includes all clients of Big 4 auditors that have headquarter address information available from COMPUSTAT and auditor office location information available from Audit Analytics. As Audit Analytics reports only the city and state in which an auditor's office is located and does not report street address, we obtain the street address from the Big 4 auditors' websites. We use Google Map to estimate the driving distance and driving time, and use the Vincenty formula to estimate the geodesic distance between zip code centroids for any two zip codes. The first three measures are estimated for the distance from a client's corporate headquarter to its lead auditor's office. The other three measures are estimated for the distance from a client's corporate headquarter to the closest Big 4 auditor office. All distances are reported in miles, and all driving times are reported in minutes. 
We next estimate the distance from a firm's corporate headquarter to the closest Big 4 auditor office. This measure will tell us whether these firms can find local Big 4 auditors. It's possible that a firm hire a remote auditor because there are no local Big 4 auditors. To our surprise, results show that $90 \%$ of the firms can find Big 4 offices within 35 miles, and the driving time is less than 44 minutes. $98 \%$ of the firms can find Big 4 offices within 115 miles, and the driving time is less than 2 hours. Taking together, these results indicate that firms do not always hire the closest Big 4 auditors. As a matter of fact, we find that $71 \%$ of firms do not hire the closest auditors.

Next, we sort out all firms that cannot find a Big 4 office within 150 miles. Surprise again, we find that there are only 41 firms in our sample that cannot find a Big 4 office within 150 miles. Six of them are headquartered in South Dakota and hire auditors in Minnesota, even though they could find closer Big 4 auditors in Billings, Montana or Omaha, Nebraska. Three of them are located in North Dakota and also hire auditors in Minnesota, even though there are closer auditor offices in Montana. Eight firms are located in Texas, three are headquartered in Idaho, three are in New Mexico, and another three are located in the state of Washington. The rest are located in Florida, Wisconsin, California, and a few other states. In general, these firms are located in remote areas or in a large state such as Texas.

In order to have a better idea about where firms' auditors are located, we next create a two-way matrix which indicates where firms' headquarters are located and where their auditors are located across the 49 states. A quite noticeable feature of Table 2 is the concentration of firms in the boxes along the diagonal, indicating that the majority of firms are audited by auditors located in the same state. For example, there are 664 firms headquartered in California, and 635 of them are audited by Big 4 offices located in California. Even though each of the 49 states has companies headquartered in it, 6 states do not have Big 4 offices. These states are Delaware, Kansas, Maine, North Dakota, South Dakota, and Wyoming. In general, firms located in these states are audited by Big 4 offices in nearby states. For example, there are 51 firms headquartered in Delaware. 36 of them are audited by Big 4 offices located in Massachusetts, one is audited by offices located in New Jersey, two are audited by auditors located in DC, and 9 of them are audited by offices located in Pennsylvania. However, two companies are audited by Big 4 offices located in Texas, and one is audited by an auditor located in Ohio. Another example is Kansas. There are 22 firms headquartered in Kansas. 21 of them are audited by Big 4 offices located in Missouri, but one company is audited by an auditor located in Nebraska. 
Table 2. Clients' headquarter locations and Big 4 auditor office locations

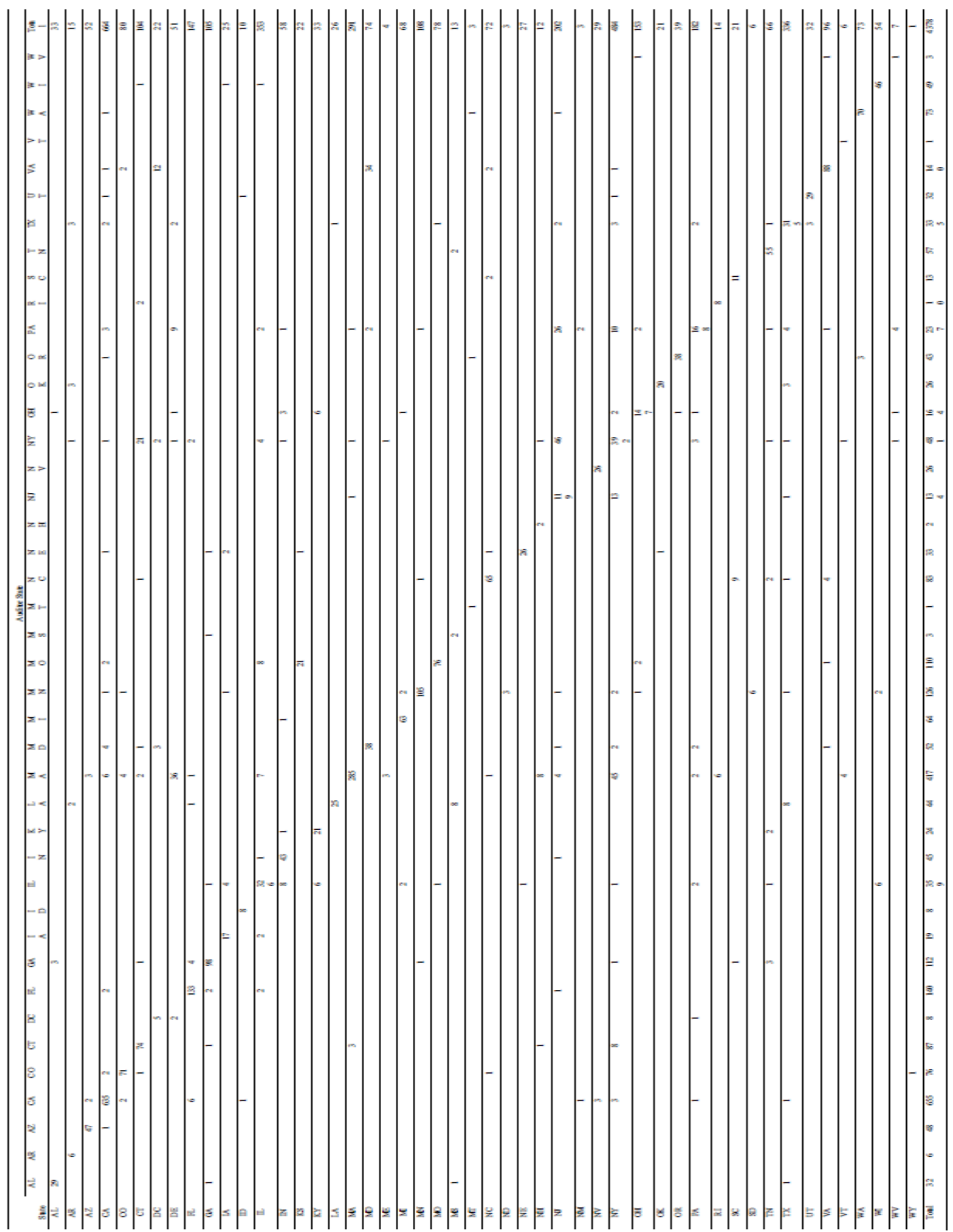

This table reports Big 4 clients' headquarter locations and their lead auditors' office locations. The first column indicates the states where the firms' headquarters are located, and the first row indicates the states where the Big 4 auditors' offices are located. The sample contains 4,378 observations for fiscal year 2005 and includes all clients of Big 4 auditors that have headquarter address information available from COMPUSTAT and auditor office location information available from Audit Analytics. 
In order to see whether firms that hire remote auditors concentrate in any specific states, we next examine only those companies that hire an auditor more than 150 miles away. Table 3 reports the distribution. In general, these firms are distributed evenly across the country. There is still the concentration of firms in the boxes along the diagonal, especially for those states with large geographic area. For example, 22 companies headquartered in Texas hire an auditor more than 150 miles away, even though these auditors are still located in Texas. Consistent with results discussed earlier, these firms have to hire remote auditors because there are no local Big 4 auditors. However, it is not clear why $45 \mathrm{New}$ York firms have to hire auditors from Massachusetts, and why so many firms from California have to hire auditors from other states.

Table 3. Clients' that hire a Big 4 auditor more than 150 miles away

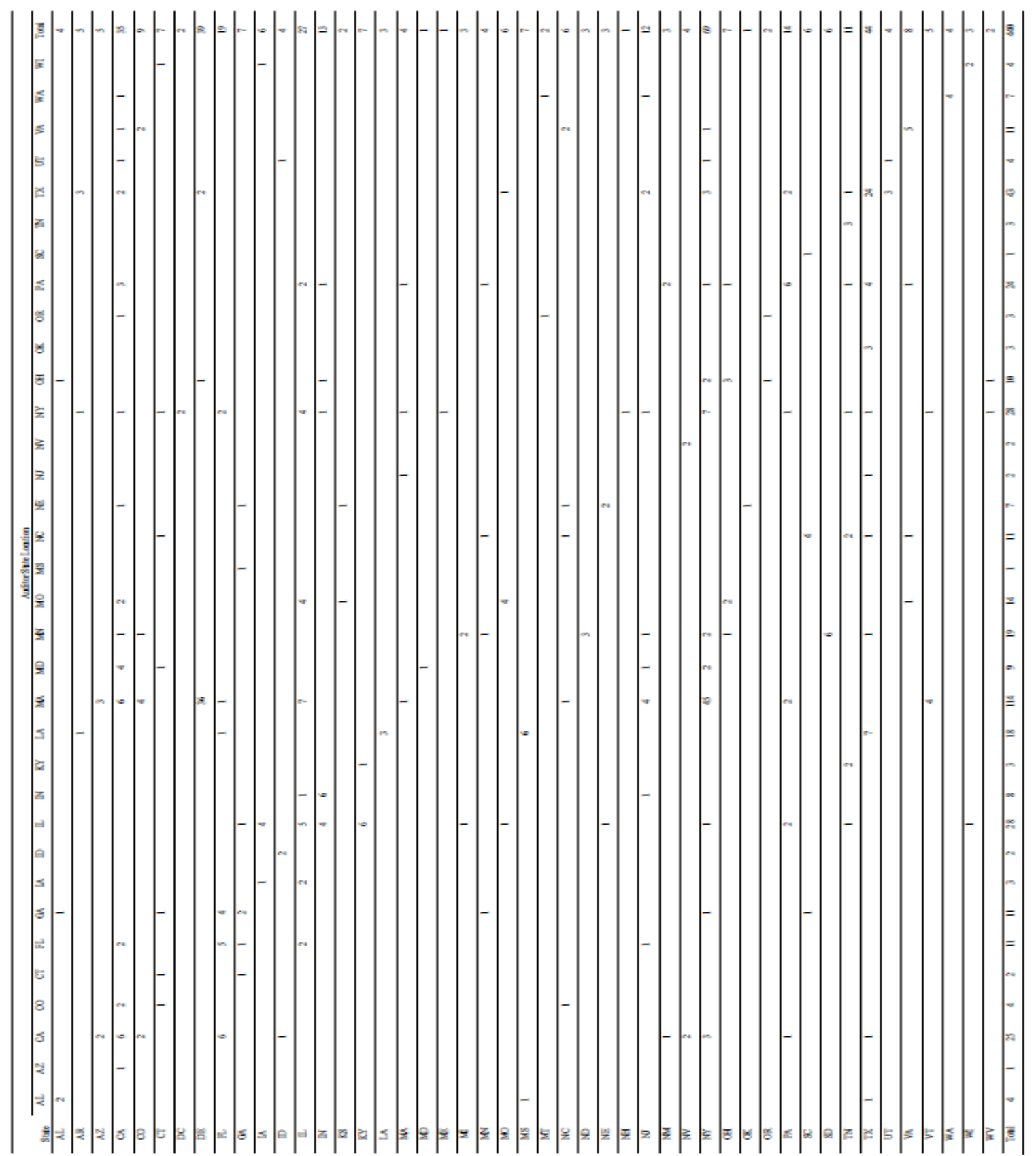

This table reports Big 4 clients' headquarter locations and their lead auditors' office locations for those firms that hire a Big 4 auditor more than 150 miles away. The first column indicates the states where the firms' headquarters are located, and the first row indicates the states where the Big 4 auditors' offices are located. The sample contains 440 observations that hire a remote auditor in fiscal year 2005. 
Table 4 reports Pearson and Spearman correlations among the variables for the multivariate analysis for the 3,588 unique firm observations in the final sample. The absolute value of abnormal accruals (ABSACCR) is significantly negatively correlated with the three distance measures in the Spearman correlation matrix, but insignificantly correlated with distance measures in the Pearson correlation matrix. One possible explanation for this opposite direction is that the accrual measure is an ex post accounting measure, i.e., the measure after earnings management has already occurred. In the analysis below, we will use the expected discretionary accruals as the testing variable to control for this endogeneity problem. Consistent with our prediction, the small positive earnings measure (DISCON) is positively correlated with distance measures and significant at $1 \%$ level, indicating that firms hiring a remote auditor are more likely to report small positive earnings. Audit fees are negatively correlated with distance and significant at $1 \%$ level. This provides some support to the explanation that clients choose remote auditors because of lower audit fees. Both the number of operating segments and the number of geographic segments are insignificantly correlated with distance. City specialist is negatively correlated with distance, which is contrary to our prediction. Table 4 also shows that distance is negatively correlated with firm size, new issue of securities, quick ratio, the number of employees, and the standard deviation of sales. It is positively correlated with a firm's operating cycle, capital intensity, and changes in sales revenue. The correlations between our testing variables and the control variables are generally smaller than $+/-0.3$, indicating that multicollinearity is probably not a concern.

Table 4. Correlations (Pearson Correlations above diagonal and spearman correlations below diagonal)

\begin{tabular}{|c|c|c|c|c|c|c|c|c|c|c|c|c|c|c|c|}
\hline Variable & LNDIST & LNTIME & LNGEO & ABSACCR & DISCON & RESTATE & AUDIT & OPSEG & GESEG & NSPECIALIST & CSPECIALIST & SIZE & CYCLE & CAPITAL & ISSUE \\
\hline LNDIST & & $0.94 * * *$ & $0.94^{* * *}$ & 0.01 & $0.04 * *$ & 0.00 & $.09 * * *$ & -.02 & 0.02 & -.01 & $.03^{*}$ & $-13^{* * *}$ & $0.03^{\circ}$ & 0.01 & $.05 * * *$ \\
\hline LNTIME & $0.96 * * *$ & & $0.95 * * *$ & .01 & $0.06 * * *$ & .00 & $-10^{4 * *}$ & .01 & 0.00 & 0.01 & $.03^{*}$ & $-.08^{* * * *}$ & $0.03^{*}$ & $0.03 * *$ & $-.08 * * *$ \\
\hline LNGEO & $0.95 * * *$ & $0.95 * * *$ & & .00 & $0.05 * * *$ & 0.00 & $-10^{4 * * 4}$ & 0.00 & 0.01 & .00 & $.03^{*}$ & $-10^{4 * *}$ & 0.03 & $0.03^{*}$ & $-.07 * * *$ \\
\hline ABSACCR & $-.03^{*}$ & $-.04 * *$ & $-.04^{* *}$ & & $-.04 * * *$ & .00 & $-.04 * *$ & -.01 & $-.06^{* * * *}$ & $-.05^{* * *}$ & $-0.04 * 4$ & $-19^{* * *}$ & $-.03^{*}$ & $-.11^{* * *}$ & $0.03^{*}$ \\
\hline DISCON & $0.06 * * *$ & $0.06^{* * *}$ & $0.05 *+*$ & $-.08+* *$ & & $0.04 * *$ & -.02 & 0.00 & $-.12^{* * *}$ & $0.05 * * *$ & $-.05 * * 4$ & $0.26^{* * *}$ & $0.44 * * *$ & $-194 * *$ & $-43^{* * *}$ \\
\hline RESTATE & .01 & -.02 & -.01 & $0.03^{*}$ & $0.04 * *$ & & $0.08 * * *$ & -.01 & $0.04 * *$ & 0.01 & 0.02 & $0.04^{* *}$ & 0.01 & $.04 * *$ & $0.03 * *$ \\
\hline AUDIT & $-.11 * * *$ & $-11 * * *$ & $-.11 * * *$ & $-.09 * * *$ & $-.04 * *$ & $0.12^{* * * *}$ & & $0.09 * * *$ & $0.17 * * *$ & 0.03 & $0.06 * * *$ & $0.27 * * *$ & $0.03^{*}$ & $-.10^{4 * 4}$ & $0.19^{* * * *}$ \\
\hline OPSEG & $.03^{*}$ & $-.03^{*}$ & -.02 & 0.00 & 0.00 & 0.01 & $0.18 * * *$ & & 0.00 & 0.02 & $0.03^{\circ}$ & $0.14^{* * *}$ & $-.04 * *$ & $0.03^{*}$ & $0.05 * * *$ \\
\hline GESEG & 0.00 & .01 & 0.00 & $-.04 * *$ & $-.17 * * 4$ & $0.04 * *$ & $0.31^{* * *+}$ & $0.04 * * *$ & & 0.00 & $0.04 * *$ & $0.04^{* *}$ & 0.01 & $0.04 * *$ & $0.16^{* * *}$ \\
\hline NSPECIALIST & -.01 & .00 & -.01 & $-.07 * * 4$ & $0.05 * * *$ & 0.01 & $0.07 * * *$ & 0.02 & .01 & & $0.17 * * *$ & $0.13 * * *$ & $0.06 * * *$ & 0.01 & $-.07 * * *$ \\
\hline CSPECIALIST & $-03^{*}$ & $-.04 * *$ & $-.03 * *$ & $-.04 * *$ & $-.05 \% * *$ & 0.02 & $0.18^{* * * *}$ & 0.03 & $0.05+\cdots$ & $0.17 * * *$ & & $0.15^{* * * *}$ & $-.06^{4 * *}$ & $0.10^{* * * *}$ & $0.05^{* * *}$ \\
\hline SIZE & $.09 * * *$ & $.08 * * *$ & $-.08 * \cdots$ & $-21^{* * *}$ & $0.24 * * *$ & $0.03^{*}$ & $0.63 * * *$ & $0.15^{* * *}$ & 0.02 & $0.13 * * *$ & $0.15 * * *$ & & $0.21 * * *$ & 0.02 & $-12 * * *$ \\
\hline CYCLE & $0.05 * * *$ & $0.05 * * *$ & $0.04 * 4$ & $-.03^{*}$ & $0.27 * * *$ & 0.03 & 0.02 & $.03^{*}$ & $0.14^{* * *}$ & 0.02 & $-.05 * * *$ & $0.08 * \cdots$ & & $-.36^{* * *}$ & $-.45^{* * *}$ \\
\hline CAPITAL & 0.00 & 0.00 & 0.01 & $-.08+* *$ & $-.29 * * *$ & -.02 & $0.07^{* * *}$ & $0.04 * * *$ & $0.11^{* * *}$ & -.01 & $0.12 * * *$ & -.01 & $-.33^{* * * *}$ & & $0.14^{* * *}$ \\
\hline ISSUE & $-.07^{* * 4}$ & $-.08+4 *$ & $-.07 * * 4$ & $0.07 * 4 *$ &. $.43^{* * *}$ & $0.03^{* *}$ & $0.22 * 4 *$ & $0.05 * * *$ & $0.21^{* * 4}$ & $-.07+4 *$ & $0.05 * * *$ & $-13^{* * *}$ & $-.274 * 4$ & $0.24 * * *$ & \\
\hline CFO & $-.04 * * *$ & $.05 * * *$ & $.03 * 4$ & -.01 & $-20^{4 * 4}$ & $-03 * *$ & $0.13 * * *$ & $0.04 * *$ & $0.05 * * *$ &. .00 & $0.04^{* *}$ & $0.14 * * *$ & $-.23^{* * 4}$ & $0.24^{* * *}$ & $0.12 * * *$ \\
\hline QUICK & -.01 & $.03^{*}$ & -.03 & $0.16^{* *+*}$ & $-22 * * *$ & 0.02 & $.08^{* * *}$ & $-.04^{* *}$ & $0.18^{* *+4}$ & $.09 * * *$ & $-.05+4 *$ & $-43^{* * *}$ & -.01 & $-.17^{4+4}$ & $0.16^{* * *}$ \\
\hline EMPLOYEE & $-.08 * 4 *$ & $-.08 * 4 *$ & $-.07+4 *$ & $-.16^{* * *}$ & $-.05 * * *$ & $0.05 * * *$ & $0.67^{* * *}$ & $0.15^{* * *}$ & $0.20 * * 4$ & $0.07 * * *$ & $0.22 * * *$ & $0.65^{* * *}$ & $-.09 * * *$ & $0.30^{* * *}$ & $0.12 * * *$ \\
\hline TURNOVER & 0.01 &. .00 & 0.01 & $0.09 * * *$ & $-36^{4 * *+}$ & 0.02 & $0.11 * * *$ & 0.00 & $0.20+* *$ & $.04 * *$ & $0.09 * \cdots$ & $-24^{* * *}$ & $-.25+* *$ & $0.40 * * *$ & $0.28^{* * * *}$ \\
\hline FOREIGN & -.01 & .02 & -.01 & $-.04 * 4$ & $-.15^{* * *}$ & $0.03^{* *}$ & $0.38 * * *$ & $0.10^{* * *}$ & $0.57 * * *$ & -.01 & $0.06 * * *$ & $0.07 * * *$ & $0.12 * * *$ & $0.11 * * *$ & $0.18^{* * *}$ \\
\hline$R \& D$ & $0.06 * * *$ & $0.04 * *$ & $0.04 * *$ & $0.05^{* * *}$ & $-.23^{* * *}$ & -.01 & $-.03^{*}$ & $-.04^{* *}$ & $0.36^{* * * *}$ & $-.10^{* * * t}$ & $-.03 * *$ & $-39 * * *$ & $0.15^{* * * *}$ & $-.04 * *$ & $0.23 * * *$ \\
\hline ZSCORE & 0.01 & -.01 & 0.01 & $0.05^{* * *}$ & $-.39 * 4 *$ & -.01 & -.01 & $-.04 * *$ & $0.20 * * 4$ & $-.06^{* * *}$ & 0.01 & $-33^{* * *}$ & $-.18^{4 * 4}$ & $0.18 * * *$ & $0.29 * * *$ \\
\hline STDREV & $-.11^{* * *}$ & $-.11^{* * *}$ & $-11^{* * *}$ & $-.11^{* * *}$ & $.05 * * *$ & $0.06^{* * *}$ & $0.69 * * *$ & $0.15 * * *$ & $0.16^{* * *}$ & $0.09 * * *$ & $0.18 * * *$ & $0.76 * * *$ & $.09 * * *$ & $0.20 * * 4$ & $0.14 * * *$ \\
\hline CHREC & 0.01 & 0.02 & 0.01 & $0.05^{* * * *}$ & $0.15 * * *$ & $-.04 * * t$ & $-.04 * 4$ & -.02 & $.03^{*}$ & $0.05 * 0 . *$ & $-.06^{* 4 *}$ & $0.05^{* * 4 *}$ & $0.15^{* * * *}$ & $-.17^{*+4}$ & $-13^{* * *}$ \\
\hline CHEARN & .01 & .02 & -.01 & $0.04^{* *}$ & $-.12^{* * *}$ & $-.05^{* * 4}$ & $0.03^{*}$ & -.01 & $0.08 * * *$ & -.00 & -.00 & 0.00 & $-09^{* * *}$ & $0.04^{* *}$ & $0.08 * * *$ \\
\hline DEBT & .02 & .01 & .00 & $-10^{4 * 4}$ & $0.09 * * *$ & $0.03^{*}$ & $0.16^{* * *}$ & $0.05^{* * *}$ & $.07+* *$ & $0.05 * * *$ & $0.08 * * *$ & $0.34 * * *$ & $-13^{* * *}$ & $0.20 * * *$ & $0.04 * *$ \\
\hline LOSS & 0.00 & .01 & -.01 & $0.12^{* * * *}$ & $.25 \% * *$ & $0.04 * *$ & $-14^{* * *}$ & $.04 * *$ & 0.02 & $.08^{* * * *}$ & .02 & $-35^{* * * *}$ & $.04 * *$ & $0.05 * * *$ & $0.11^{* * * *}$ \\
\hline $\mathrm{ROA}$ & .03 & .03 & .02 & $-.03^{* *}$ & $-29^{* * * *}$ & $.09 * * *$ & $0.14^{* * *}$ & $0.04 * *$ & $0.10^{* * * *}$ & 0.02 & 0.03 & $0.14^{* * *}$ & $-.12^{* * *}$ & $0.10^{* * * *}$ & $0.14^{* * *}$ \\
\hline CHSALE & -.01 & -01 & -.01 & $0.14^{* * *}$ & $.22 * * *$ & $-04^{* *}$ & $0.04 * * *$ & 0.01 & $0.07+4 *$ & .01 & $0.03^{* *}$ & $-10^{4 * *}$ & $-23 * * *$ & $0.13^{* * *}$ & $0.22^{* * *}$ \\
\hline
\end{tabular}

\begin{tabular}{|c|c|c|c|c|c|c|c|c|c|c|c|c|c|c|}
\hline Variable & CFO & QUICK & EMPLOYEE & TURNOVER & FOREIGN & $R \& D$ & ZSCORE & STDREV & CHREC & CHEARN & DEBT & LOSS & $\mathrm{ROA}$ & CHSALE \\
\hline LNDIST & 0.02 & 0.01 & $-.06^{* *+*}$ & $0.04 * *$ & -.00 & $0.03^{*}$ & $0.04 * *$ & $-.08 * * *$ & 0.01 & 0.00 & -.03 & 0.00 & -.02 & $0.03^{* *}$ \\
\hline LNTME & 0.03 & $-.03 * *$ & $-.05+4 *$ & 0.01 & -.03 & .00 & 0.01 & $-.07 * * *$ & 0.02 & -.00 & -.01 & -.01 & -.01 & $0.04 * *$ \\
\hline LNGEO & 0.03 & $-.03^{* *}$ & $-.06^{* * * *}$ & 0.02 & -.02 & -.01 & 0.02 & $-.07 * * *$ & 0.01 & 0.00 & .01 & -.02 & 0.00 & $0.03 * *$ \\
\hline ABSACCR & $-18^{* * * *}$ & $0.14 * * *$ & $-.06^{* * *}$ & $0.05 * * *$ & $-.08 * * *$ & $0.10^{* * *}$ & $-.03^{*}$ & $-.04 * * *$ & $0.18 * * *$ & 0.02 &. .00 & $0.12 * * *$ & $-13^{* * *}$ & $0.21 * * *$ \\
\hline DISCON & -.01 & $-22 * * *$ & -.03 & $-25+\cdots$ & $-.15 * * *$ & $-14 * * *$ & $-28 * * *$ & -.01 & $0.15^{* * * *}$ & -.02 & $0.04 * *$ & $-.25 * \cdots$ & $0.03^{*}$ & $-12 * * *$ \\
\hline RESTATE & 0.00 & -.01 & 0.01 & 0.02 & $0.03 * *$ & $-.04 * * *$ & -.01 & 0.01 & $-.03^{*}$ & -.03 & $0.03 * *$ & $0.04 * *$ & 0.01 & -.02 \\
\hline AUDIT & $0.03^{*}$ & $-.03^{*}$ & $0.16^{* * * *}$ & $0.05 * \cdots$ & $0.23 \cdots * *$ & $-.05 * * *$ & 0.02 & $0.18^{* * *}$ & -.01 & 0.02 & $-.04 * *$ & $-.05 * * *$ & $0.08 * * *$ & 0.00 \\
\hline OPSEG & 0.01 & $-.06^{* * * *}$ & $0.05 * * *$ & -.01 & $0.07 * * *$ & $-.04 * *$ & $-.04 * *$ & $0.12 * * *$ & -.01 & -.02 & $0.04 * *$ & $-.03^{*}$ & 0.02 & -.01 \\
\hline GESEG & 0.02 & $0.06 * * *$ & $0.05 * * *$ & $0.04 * *$ & $0.47 * * *$ & $0.04 * *$ & $0.09 * * *$ & $0.08^{* * *}$ & $-.04 * *$ & 0.02 & $-.05 * * *$ & 0.02 & $0.04 * *$ & -.02 \\
\hline NSPECIALIST & 0.02 & $-.09 * * *$ & $0.07 * * *$ & $.03^{*}$ & -.01 & $-.08 * * *$ & $-.03^{*}$ & $0.07 * *$ & 0.01 & 0.01 & 0.00 & $-.08 * \cdots$ & $0.06^{* * *}$ & -.01 \\
\hline CSPECIALIST & -.01 & $-.07 * * *$ & $0.08 * * *$ & $0.06 * * *$ & $0.06 * *$ & $-.05 * *$ & -.01 & $0.08 * * *$ & $-.06 * * *$ & -.02 & $0.05 * *$ & -.02 & 0.02 & 0.01 \\
\hline SIZE & $0.08 * * *$ & $-.46^{* * *}$ & $0.30^{* * *}$ & $-21^{* * *}$ & $0.08 * * *$ & $-.40^{* * * *}$ & $-26^{* * *}$ & $0.37^{* * *}$ & $0.03^{*}$ & -.02 & $0.12 * * *$ & $-.35 * * *$ & $0.31 * * *$ & $-10 * * *$ \\
\hline CYCLE & $-.07 * * *$ & $-.14 * * *$ & $-.05 * * *$ & $-32 * * *$ & -.01 & $-.08 * * *$ & $-24 * \cdots$ & -.02 & $0.27 * * *$ & $-.04 * *$ & $-.13 * * *$ & $-.10 * 4$ & 0.00 & $-19 * * *$ \\
\hline CAPITAL & $0.05 * *$ & $-24 * *$ & $0.07 * * *$ & $0.15 * * *$ & 0.01 & $-.06 * *$ & $-.03 * *$ & $0.04 * * *$ & $-17 * * *$ & $-\infty$ & $0.20 * *$ & 0.02 & -.03 & $-03^{*}$ \\
\hline ISSUE & $-.06 * * *$ & $0.15^{* * *}$ & $0.05 * * *$ & $0.16^{* * *}$ & $0.18^{* * *}$ & $0.13 * * *$ & $0.18 * * *$ & $0.04 * *$ & $-12 * *$ & -.01 & $0.04 * *$ & $0.11^{* * *}$ & $-.03 * *$ & $0.11 \cdots$ \\
\hline CFO & & $-11 * * *$ & 0.02 & $0.25 * * *$ & $0.07 * *$ & $-.24 * * *$ & $0.28 * * *$ & 0.03 & $-.06 * *$ & $0.27^{* * * *}$ & $-.07 * * *$ & $-.27 * * *$ & $0.42 * * *$ & $0.15^{\circ * *}$ \\
\hline QUICK & $0.03^{*}$ & & $-.09 * 4 *$ & $-10^{* * * *}$ & $0.06 * *$ & $0.55 * * *$ & $0.22 * \cdots$ & $-.08 * * *$ & $-.09 * \cdots$ & $0.05^{* * *}$ & $-30 * 4 *$ & $0.31 * *$ & $-27 * * *$ & 0.02 \\
\hline EMPLOYEE & $0.27 * * *$ & $-25^{* * *}$ & & $0.11 * * *$ & $0.12 * * *$ & $-.07^{* * *}$ & 0.03 & $0.45^{* * *}$ & $-.04 * *$ & -.01 & -.01 & $-.08 * * *$ & $0.06^{* * * *}$ & 0.01 \\
\hline TURNOVER & $0.32 * * *$ & $0.04 * *$ & $0.37 * * *$ & & $0.10 * * *$ & $-.14 * * *$ & $0.56 * * *$ & $0.08 * * *$ & $-.04 * *$ & $0.13^{* * * *}$ & $-.05 * * *$ & $-.06^{* * *}$ & $0.15^{* * * *}$ & $0.40^{* * * *}$ \\
\hline FOREIGN & $0.11 * * *$ & $0.17^{* * * *}$ & $0.27 * * *$ & $0.23 * * *$ & & 0.01 & $0.14^{* * * *}$ & $0.08^{* * *}$ & $-.09 * * *$ & 0.02 & $-.07 * * *$ & -.01 & $0.10^{* * * *}$ & -.02 \\
\hline$R \& D$ & $-15^{* * *}$ & $0.56 * * *$ & $-24^{* * *}$ & -.01 & $0.33^{* * *}$ & & $-20 * * *$ & $-.07 * \cdots$ & $-.08 * \cdots$ & $-.06^{* * *}$ & $-.09 * * *$ & $0.40^{* * *}$ & $-.63^{* * *}$ & $-.05 * *$ \\
\hline ZSCORE & $0.44 * * *$ & $0.30 * * *$ & $0.13 * * *$ & $0.70^{* * * *}$ & $0.22^{* * *}$ & $0.16^{* * *}$ & & 0.01 & -.03 & $0.17 * * *$ & $-.33 * * *$ & $-.21 * *$ & $0.49 * * *$ & $0.28 * * *$ \\
\hline STDREV & $0.26 * * *$ & $-25^{* * *}$ & $0.75 * * *$ & $0.23 * * *$ & $0.21 * *$ & $-.26 * * *$ & $0.06 * * *$ & & -.02 & 0.01 & -.02 & $-.08 * * *$ & $0.06^{* * * *}$ & $0.06^{* * * *}$ \\
\hline CHREC & -.01 & $-.08 * * *$ & $-.05 * * *$ & $-.05 * * *$ & $-.06 * * *$ & $.09 * * *$ & -.01 & 0.00 & & 0.02 & $-.03^{*}$ & $-.11 * * *$ & $0.09 * * *$ & $0.40^{* * * *}$ \\
\hline CHEARN & $0.36^{* * *}$ & $0.09 * * *$ & $0.04 * *$ & $0.14 * * *$ & $0.07 * *$ & 0.01 & $0.23 * * *$ & $0.09 * * *$ & $0.15 * * *$ & & .01 & $-.21 * *$ & $0.30 * * *$ & $0.17 * * *$ \\
\hline DEBT & $-.08 * \cdots$ & $-51 * * *$ & $0.21 * *$ & $-10 * *$ & $-.07 \%$ & $-31^{* * *}$ & $-.43 * * *$ & $0.21 * * *$ & $-.06^{* * *}$ & $-.05 * * *$ & & $0.13 * * *$ & $-12 * *$ & $-.04 * *$ \\
\hline LOSS & $-54 * * *$ & $0.25 * * *$ & $-24 * * *$ & $-.07 * * *$ & -.01 & $0.32 * * *$ & $-21^{* * *}$ & $-.28 * * *$ & $-20 * * *$ & $-31^{* * *}$ & 0.01 & & $-.58 * * \cdot$ & $-.12 * * *$ \\
\hline ROA & $0.77 * * *$ & 0.01 & $0.26^{* * *}$ & $0.35 * *$ & $0.13 * *$ & $-.13 * *$ & $0.55 * * *$ & $0.28^{* * *}$ & $0.13 * * *$ & $0.46^{* * *}$ & $-.16^{* * *}$ & $-.73 * * *$ & & $0.14^{* * * *}$ \\
\hline CHSALE & $0.31 * * *$ & $0.06 * * *$ & $0.12 * * *$ & $0.43^{* * *}$ & $0.06^{* * *}$ & -.01 & $0.40^{* * *}$ & $0.16^{* * *}$ & $0.41^{* * *}$ & $0.34^{* * *}$ & $-.07 * * *$ & $-.20^{* * * *}$ & $0.37 * * *$ & \\
\hline
\end{tabular}

$* * *, * *$, and $*$ indicate significance at the $1 \%, 5 \%$, and $10 \%$ level, respectively. 
This table reports the Pearson and Spearman correlations among major variables used in this study. The sample consists of 3,588 observations for the fiscal year 2005. LINDIST is the log-transformed driving distance from a client's headquarter to its auditor's office. LINTIME is the log-transformed driving time from a client's headquarter to its auditor's office. Both driving distance and driving time are estimated using Google Map. LINGEO is the log-transformed geodesic distance between zip code centroids for any two zip codes. We use the Vincenty formula to estimate the geodesic distance. ABSACCR is the absolute value of the performance adjusted abnormal accruals. DISCON is a dummy variable that takes the value of one if a firm reports small positive earnings and zero otherwise. RESTATE is a dummy variable that takes the value of one if a firm restated its financial statements and zero otherwise. AUDIT is the log-transformed audit fees. OPSEG is the number of operating segments, and GESEG is the number of geographic segments. NSPECIALIST is a dummy variable that takes the value of one if an auditor is the number one auditor in an industry in terms of aggregated audit fees in a specific fiscal year and zero otherwise. CSPECIALIST is a dummy variable that takes the value of one if an office is the number one auditor in terms of aggregated client audit fees in an industry within that city in a specific fiscal year and zero otherwise. SIZE is the natural log of total assets. CYCLE is a firm's operating cycle which is calculated as the sum of days' inventory and days' accounts receivable divided by 30 , where days' inventory is calculated as 365 times the average of the beginning and ending inventory divided by the cost of goods sold, and days' accounts receivable is calculated as 365 times the average of the beginning and ending accounts receivable divided by sales. CAPITAL is the measure of capital intensity which is the ratio of gross property, plant, and equipment to total assets. ISSUE is the proxy of new issue of securities which is a dummy variable that takes the value of one if a firm issues equity or debt securities during the year and zero otherwise. CFO is defined as the difference between net income and total accruals, while total accruals are derived from the balance sheet accounts. QUICK is quick ratio which is defined as the ratio of the sum of cash and marketable securities to total assets. EMPLOYEE is the number of employees in millions. TURNOVER is asset turnover which is the ratio of sales to total assets. FOREIGN is a dummy variable that takes the value of one if a firm reports foreign sales and zero otherwise. R\&D is the measure of R\&D intensity which is defined as the total R\&D expense deflated by total assets. ZSCORE is the Altman Z-score. STDREV is the standard deviation of revenues. We use a rolling window up to 10 years to estimate the standard deviation revenues. CHREC is change in receivables and CHEARN is change in net income. Both of these two measures are deflated by total assets. DEBT is the ratio of long-term debt to total assets. LOSS is a dummy variable that takes the value of one if net income is negative and zero otherwise. ROA is the ratio of net income to total assets. CHSALE is the measure of sales growth.

\subsection{Regression Analysis}

We first regress the log-transformed measures of distance on those testing variables and a set of control variables. We use OLS to estimate this equation with White (1980) robust standard errors to control for heteroscedasticity. The first regression uses the log-transformed driving distance as the dependent variable, and the second regression uses the log-transformed driving time as the dependent variable. In the third regression, we regress the log-transformed straight-line (geodesic) distance on those testing and control variables. Consistent with the results in Table 4, the coefficient of DISCON is positively significant across all three regressions, indicating that firms reporting small positive earnings tend to hire a remote auditor. Also consistent with Table 4, Audit fees are negatively correlated with distance measures and significant at the conventional level, supporting the story that firms hire a remote auditor because of competitive audit fees offered by that auditor. Geographic distance is only positively significant at the conventional level in the third regression, but weakly significant at $10 \%$ level (one-tail) in the first and second regression. So the results provide some support to the diversified geographic segments explanation. None of the auditor specialist measures are significant.

Firm size is negatively correlated with all distance measures and significant at $1 \%$ level, indicating that small firms tend to hire remote auditors. Quick ratio is also negatively correlated with distance measures, suggesting that firms that tend to hire non-local auditors have lower cash holdings. The number of employees is also negatively correlated with distance measures, indicating that firms hiring remote auditors tend to have smaller number of employees. All regressions include two-digit SIC code dummies and state dummies. For brevity, coefficients on these dummies are not reported.

\subsection{Why Hire an Auditor 500 Miles Away?}

The distance to an auditor's office is apparently a skewed distribution. Moreover, from an economic perspective, there is a large difference between a firm being 300 miles from its auditor rather than 55 miles from its auditor, while there is probably little difference between it being 55 miles instead of 25 miles from its auditor. Both the skewness and the 
likely nonlinearity of the economic impact of distance suggest using continuous measures of distance to test our hypotheses may be biased. As an alternative, we construct a few dichotomous measures of distance and retest the results reported in Table 5. The first dummy is coded as 1 if a firm hires a Big 4 office more than 150 miles away and 0 otherwise. The second one is coded as 1 if a firm hires an office more than 300 miles away and 0 otherwise. And the last dummy is coded as 1 if a firm hires a Big 4 office more than 500 miles from its headquarter and 0 otherwise.

Table 5. Factors inducing firms to choose a remote auditor

\begin{tabular}{|c|c|c|c|c|c|c|c|}
\hline \multirow{3}{*}{$\begin{array}{l}\text { Independent } \\
\text { Variables }\end{array}$} & \multirow{3}{*}{$\begin{array}{c}\text { Predicted } \\
\text { Sign }\end{array}$} & \multicolumn{6}{|c|}{ Dependent Variable $=$ Distance Proxies } \\
\hline & & \multicolumn{2}{|c|}{ Natural Log of Driving Distance } & \multicolumn{2}{|c|}{ Natural Log of Driving Time } & \multicolumn{2}{|c|}{ Natural Log of Geodesic Distance } \\
\hline & & Coefficient & $\mathrm{t}$-value & Coefficient & $\mathrm{t}$-value & Coefficient & t-value \\
\hline ABSACCR & + & 0.460 & 1.08 & 0.282 & 0.93 & 0.354 & 0.94 \\
\hline DISCON & + & $0.233^{* *}$ & 2.22 & $0.133^{*}$ & 1.83 & $0.166^{*}$ & 1.90 \\
\hline RESTATE & + & 0.028 & 0.36 & 0.026 & 0.50 & 0.041 & 0.62 \\
\hline AUDIT & - & $-0.036^{* *}$ & -2.10 & $-0.023 *$ & -1.85 & $-0.036 * *$ & -2.40 \\
\hline OPSEG & + & 0.053 & 0.83 & 0.036 & 0.80 & 0.07 & 1.42 \\
\hline GESEG & + & 0.025 & 1.44 & 0.017 & 1.42 & $0.026^{*}$ & 1.81 \\
\hline NSPECIALIST & + & 0.007 & 0.10 & 0.017 & 0.36 & 0.011 & 0.19 \\
\hline CSPECIALIST & + & -0.047 & -0.73 & -0.051 & -1.15 & -0.062 & -1.13 \\
\hline SIZE & $?$ & $-0.105^{* * *}$ & -4.30 & $-0.061 * * *$ & -3.66 & $-0.083^{* * *}$ & -4.09 \\
\hline CYCLE & $?$ & -0.022 & -0.55 & -0.032 & -1.18 & -0.024 & -0.71 \\
\hline CAPITAL & $?$ & -0.08 & -0.68 & -0.028 & -0.34 & -0.053 & -0.53 \\
\hline ISSUE & $?$ & -0.078 & -0.51 & -0.142 & -1.32 & -0.131 & -1.02 \\
\hline $\mathrm{CFO}$ & $?$ & 0.119 & 1.44 & 0.101 & 1.54 & 0.111 & 1.38 \\
\hline QUICK & $?$ & $-0.312^{*}$ & -1.64 & $-0.261^{*}$ & -1.96 & $-0.401^{* *}$ & -2.41 \\
\hline EMPLOYEE & $?$ & $-1.141^{*}$ & -1.75 & $-0.704 *$ & -1.73 & $-1.096 * *$ & -2.09 \\
\hline TURNOVER & $?$ & -0.031 & -0.52 & -0.046 & -1.05 & -0.067 & -1.24 \\
\hline FOREIGN & $?$ & 0.001 & 0.01 & -0.015 & -0.30 & -0.005 & -0.08 \\
\hline$R \& D$ & $?$ & -0.077 & -0.22 & -0.029 & -0.12 & -0.06 & -0.19 \\
\hline ZSCORE & $?$ & 0.029 & 1.17 & 0.019 & 1.02 & 0.029 & 1.29 \\
\hline STDREV & $?$ & -0.196 & -1.09 & -0.145 & -1.43 & -0.169 & -1.41 \\
\hline CHREC & $?$ & -0.326 & -0.81 & -0.055 & -0.19 & -0.159 & -0.45 \\
\hline CHEARN & $?$ & -0.088 & -0.50 & -0.035 & -0.28 & 0.002 & 0.01 \\
\hline State Dummies & & & YES & & YES & & YES \\
\hline \multicolumn{8}{|l|}{ Industry } \\
\hline Dummies & & & YES & & YES & & YES \\
\hline \multicolumn{8}{|l|}{ Number of } \\
\hline Observations & & & 3,588 & & 3,588 & & 3,588 \\
\hline R-Square & & & 0.14 & & 0.14 & & 0.15 \\
\hline
\end{tabular}

***, $* *$, and $*$ indicate significance at the $1 \%, 5 \%$, and $10 \%$ level, respectively.

This table reports the results of OLS estimates with robust standard errors to correct for heteroscedasticity. Two-digit SIC industry dummies and state dummies are included to control for industry and state fixed effects and are not reported for brevity. The dependent variable in the first regression is the log-transformed driving distance from a client's headquarter to its auditor's office, and the dependent variable in the second regression is the log-transformed driving time from a client's headquarter to its auditor's office. Both the driving distance and driving time are estimated using Google Map. The dependent variable in the third regressions is the log-transformed geodesic distance between zip code centroids for any two zip codes. We use the Vincenty formula to estimate the geodesic distance. ABSACCR is the absolute value of the performance adjusted abnormal accruals. DISCON is a dummy variable that takes the value of one if a firm reports small positive earnings and zero otherwise. RESTATE is a dummy variable that takes the value of one if a firm restated its financial statements and zero otherwise. AUDIT is the log-transformed audit fees. OPSEG is 
the number of operating segments, and GESEG is the number of geographic segments. NSPECIALIST is a dummy variable that takes the value of one if an auditor is the number one auditor in an industry in terms of aggregated audit fees in a specific fiscal year and zero otherwise. CSPECIALIST is a dummy variable that takes the value of one if an office is the number one auditor in terms of aggregated client audit fees in an industry within that city in a specific fiscal year and zero otherwise. SIZE is the natural log of total assets. CYCLE is a firm's operating cycle which is calculated as the sum of days' inventory and days' accounts receivable divided by 30 , where days' inventory is calculated as 365 times the average of the beginning and ending inventory divided by the cost of goods sold, and days' accounts receivable is calculated as 365 times the average of the beginning and ending accounts receivable divided by sales. CAPITAL is the measure of capital intensity which is the ratio of gross property, plant, and equipment to total assets. ISSUE is the proxy of new issue of securities which is a dummy variable that takes the value of one if a firm issues equity or debt securities during the year and zero otherwise. CFO is defined as the difference between net income and total accruals, while total accruals are derived from the balance sheet accounts. QUICK is quick ratio which is defined as the ratio of the sum of cash and marketable securities to total assets. EMPLOYEE is the number of employees in millions. TURNOVER is asset turnover which is the ratio of sales to total assets. FOREIGN is a dummy variable that takes the value of one if a firm reports foreign sales and zero otherwise. $R \& D$ is the measure of $R \& D$ intensity which is defined as the total $R \& D$ expense deflated by total assets. ZSCORE is the Altman Z-score. STDREV is the standard deviation of revenues. We use a rolling window up to 10 years to estimate the standard deviation revenues. CHREC is change in receivables and CHEARN is change in net income. Both of these two measures are deflated by total assets.

As we discussed earlier, Table 4 shows that the discretionary accruals measure is either insignificant or correlated with distance measures in the opposite direction. It is possible that the discretionary accruals measure is endogenous, as the measure is constructed on accounting numbers after the earnings management has already occurred. In order to mitigate this effect, we use the following regression to estimate the expected discretionary accruals:

$$
\mathrm{ABSACCR}=\lambda_{0}+\mathbf{X}^{\prime} \boldsymbol{\lambda}+\ddot{v}
$$

we use OLS to estimate this equation with White (1980) robust standard errors to control for heteroscedasticity. As in Francis and $\mathrm{Yu}$ (2009), two-digit SIC codes are also included to control for industry fixed effects. The dependent variable in equation (2) is the absolute value of abnormal accruals (ABSACCR) as we defined earlier. $\mathbf{X}$ is a vector of independent variables that includes firm size (SIZE), inventory level (INVENTORY), net operating cash flows (CFO), quick ratio (QUICK), assets turnover (TURNOVER), a summary measure of financial distress Altman z-score (ZSCORE), standard deviation of net operating cash flows (STDCFO), accounts receivable growth (CHREC), new issue of securities (ISSUE), debt ratio (DEBT), a dummy variable indicating whether the company reports loss in the current fiscal year (LOSS), return on assets (ROA), and sales growth (CHSALE). (Note 19)

After we estimate the expected absolute value of discretionary accruals from Equation (2), we use the following probit model to test the hypothesis why a firm would choose a remote auditor:

$$
\text { PROBIT [REMOTE_AUDITOR }=1]=f\left(\beta_{0}+\beta_{1} \text { ABSACCR_HAT }+\mathbf{X}^{\prime} \boldsymbol{\beta}+\varepsilon\right)
$$

where REMOTE_AUDITOR is a dummy variable that takes the value of 1 if a firm choose a remote auditor and 0 otherwise. As discussed earlier, we use three different cut-offs to define remote auditors: 150 miles, 300 miles, and 500 miles. Following Gould et al. (2006), we use MLE to estimate this model with robust standard errors. Two-digit SIC code dummies and state dummies are also included. ABSACCR_HAT is the expected absolute value of discretionary accruals estimated from Equation (2). $\mathbf{X}$ is a vector of testing and control variables that is the same as those in Equation (1) for continuous measures of distance.

Table 6 reports the results. As we predicted, the estimated absolute value of discretionary accruals is positively correlated with remote auditors across the three regressions and significant at $1 \%$ level. In the first regression, the coefficient of ABSACCR_HAT is 19.33 and the t-value is 3.45. In the second regression, the coefficient of ABSACCR_HAT is $29.72 \overline{3}$ and the t-value is 4.80 . In the third regression, the coefficient of ABSACCR_HAT is 29.544 and $\mathrm{t}$-value is 3.83. (Note 20) Consistent with the results in Table 5, the coefficient on GESEG is positive and significant at $10 \%$ or $5 \%$ level across the three regressions, indicating that geographically diversified clients tend to hire remote auditors. Even though the coefficients on audit fees (AUDIT) are still negative but they become insignificant, indicating that competitive audit pricing explanation is probably only valid within 150 miles. Once an auditor is more than 150 miles away, it is unlikely for that auditor to offer more competitive audit pricing than local auditors. Finally, none of the auditor specialist measures is significant across the three regressions. 
Table 6 . Why choose an auditor 500 miles away?

\begin{tabular}{|c|c|c|c|c|c|c|c|}
\hline \multirow{3}{*}{$\begin{array}{l}\text { Independent } \\
\text { Variables }\end{array}$} & \multirow{3}{*}{$\begin{array}{c}\text { Predicted } \\
\text { Sign }\end{array}$} & \multicolumn{6}{|c|}{ Dependent Variable $=$ Distance Proxies } \\
\hline & & \multicolumn{2}{|c|}{ Dummy (Distance $>150=1$ ) } & \multicolumn{2}{|c|}{ Dummy (Distance $>300=1$ ) } & \multicolumn{2}{|c|}{ Dummy (Distance $>500=1$ ) } \\
\hline & & Coefficient & z-value & Coefficient & $z$-value & Coefficient & $z$-value \\
\hline ABSACCR_HAT & + & $19.33 * * *$ & 3.45 & $29.723 * * *$ & 4.80 & $29.544 * * *$ & 3.83 \\
\hline DISCON & + & 0.23 & 1.08 & 0.006 & 0.02 & 0.21 & 0.65 \\
\hline RESTATE & + & 0.006 & 0.03 & 0.356 & 1.62 & $0.487^{*}$ & 1.74 \\
\hline AUDIT & - & -0.016 & -0.61 & -0.048 & -1.45 & -0.058 & -1.42 \\
\hline OPSEG & + & 0.029 & 0.25 & 0.179 & 1.51 & 0.243 & 1.59 \\
\hline GESEG & + & $0.077 *$ & 1.74 & $0.112^{* *}$ & 2.40 & $0.111^{* *}$ & 2.37 \\
\hline NSPECIALIST & + & 0.117 & 0.78 & 0.078 & 0.39 & 0.148 & 0.58 \\
\hline CSPECIALIST & + & -0.014 & -0.09 & -0.004 & -0.02 & -0.046 & -0.18 \\
\hline SIZE & $?$ & 0.1 & 1.55 & $0.25^{* * *}$ & 3.14 & $0.306^{* * *}$ & 2.57 \\
\hline CYCLE & $?$ & $-0.203 * *$ & -2.42 & $-0.231^{* *}$ & -2.14 & -0.219 & -1.50 \\
\hline CAPITAL & $?$ & 0.096 & 0.38 & -0.062 & -0.16 & $-1.033^{* *}$ & -2.06 \\
\hline ISSUE & $?$ & -0.323 & -1.25 & -0.413 & -1.22 & $-0.88^{* *}$ & -2.13 \\
\hline CFO & $?$ & $1.061 * * *$ & 4.19 & $1.013^{* * *}$ & 4.14 & $1.054 * * *$ & 3.80 \\
\hline QUICK & $?$ & $-2.068 * * *$ & -3.26 & $-2.181 * * *$ & -3.07 & $-2.4 * * *$ & -2.73 \\
\hline EMPLOYEE & ? & -4.638 & -1.25 & -2.042 & -0.62 & -2.614 & -0.76 \\
\hline TURNOVER & $?$ & $-0.581 * * *$ & -3.33 & $-0.567 * * *$ & -2.92 & $-0.523^{* *}$ & -2.16 \\
\hline FOREIGN & $?$ & -0.306 & -1.45 & -0.326 & -1.30 & -0.1 & -0.34 \\
\hline $\mathrm{R} \& \mathrm{D}$ & ? & -0.468 & -0.41 & -2.098 & -1.00 & -1.885 & -0.88 \\
\hline ZSCORE & $?$ & $0.215^{* *}$ & 2.48 & $0.241^{* *}$ & 2.02 & 0.167 & 1.03 \\
\hline STDREV & ? & -0.281 & -0.84 & -0.585 & -1.12 & -1.858 & -1.32 \\
\hline CHREC & $?$ & -2.624 & -1.55 & $-5.799 * * *$ & -3.17 & $-5.447 * *$ & -2.22 \\
\hline CHEARN & $?$ & $-0.946 * * *$ & -2.64 & -0.11 & -0.23 & 0.183 & 0.35 \\
\hline State Dummies & & & YES & & YES & & YES \\
\hline Industry Dummies & & & YES & & YES & & YES \\
\hline \multicolumn{8}{|l|}{ Number of } \\
\hline Observations & & & 3,349 & & 2,843 & & 2,357 \\
\hline Wald Chi2 & & & 363 & & 232 & & 212 \\
\hline Pseudo R-Square & & & 0.16 & & 0.14 & & 0.14 \\
\hline
\end{tabular}

$* * *, * *$, and $*$ indicate significance at the $1 \%, 5 \%$, and $10 \%$ level, respectively.

This table reports the results of probit model estimates with robust standard errors to correct for heteroscedasticity. Two-digit SIC industry dummies and state dummies are included to control for industry and state fixed effects and are not reported for brevity. The dependent variable in the first regression is a dummy variable that takes the value of one if a firm chooses an auditor more than 150 miles away from its headquarter and zero otherwise. The dependent variable in the second regression is a dummy variable that takes the value of one if a firm chooses an auditor more than 300 miles away from its headquarter and zero otherwise. The dependent variable in the third regression is a dummy variable that takes the value of one if a firm chooses an auditor more than 500 miles away from its headquarter and zero otherwise. ABSACCR_HAT is the expected absolute value of discretionary accruals estimated from Equation (2). DISCON is a dummy variable that takes the value of one if a firm reports small positive earnings and zero otherwise. RESTATE is a dummy variable that takes the value of one if a firm restated its financial statements and zero otherwise. AUDIT is the log-transformed audit fees. OPSEG is the number of operating segments, and GESEG is the number of geographic segments. NSPECIALIST is a dummy variable that takes the value of one if an auditor is the number one auditor in an industry in terms of aggregated audit fees in a specific fiscal year and zero otherwise. CSPECIALIST is a dummy variable that takes the value of one if an office is the number one auditor in terms of aggregated client audit fees in an industry within that city in a specific fiscal year and zero otherwise. SIZE is the natural log of total assets. 
CYCLE is a firm's operating cycle which is calculated as the sum of days' inventory and days' accounts receivable divided by 30 , where days' inventory is calculated as 365 times the average of the beginning and ending inventory divided by the cost of goods sold, and days' accounts receivable is calculated as 365 times the average of the beginning and ending accounts receivable divided by sales. CAPITAL is the measure of capital intensity which is the ratio of gross property, plant, and equipment to total assets. ISSUE is the proxy of new issue of securities which is a dummy variable that takes the value of one if a firm issues equity or debt securities during the year and zero otherwise. CFO is defined as the difference between net income and total accruals, while total accruals are derived from the balance sheet accounts. QUICK is quick ratio which is defined as the ratio of the sum of cash and marketable securities to total assets. EMPLOYEE is the number of employees in millions. TURNOVER is asset turnover which is the ratio of sales to total assets. FOREIGN is a dummy variable that takes the value of one if a firm reports foreign sales and zero otherwise. $R \& D$ is the measure of $R \& D$ intensity which is defined as the total $R \& D$ expense deflated by total assets. ZSCORE is the Altman Z-score. STDREV is the standard deviation of revenues. We use a rolling window up to 10 years to estimate the standard deviation revenues. CHREC is change in receivables and CHEARN is change in net income. Both of these two measures are deflated by total assets.

Table 6 also shows that clients hiring remote auditors are more likely to have higher net cash flow from operating activities, and lower quick ratio and asset turnover ratio. The results also show that clients that are more likely to have financial restatements tend to hire an auditor more than 500 miles away. However, this is not the case if we use 150 miles or 300 miles as the cutoff to define remote auditor. This finding suggests that the severity of earnings management increases with distance. Firm size (SIZE) becomes positively significant in the second and third regression, indicating that on average clients hiring auditors more than 300 miles from their headquarters are bigger than those hiring local auditors. In addition, results show that clients hiring a remote auditor more than 500 miles away tend to have lower capital intensity, are less likely to issue securities, and have lower accounts receivable growth. (Note 21)

\subsection{Does Audit Fee Affect Office Choice?}

As we reported earlier, firms located in rural areas cannot find local Big 4 auditors. For these firms, it probably does not make a big difference whether to hire an office located 500 miles away or the closest office located 450 miles away. It is also hard to argue that the preference is purely driven by earnings management motivation. Furthermore, it would be difficult to argue that the difference between hiring an office 30 miles away instead of the closest one located 20 miles away is non-trivial, and it would be also difficult to argue that there is any motivation behind the choice. It is also possible that the situation faced by firms that can find local big 4 auditors within 20 miles is different from that faced by firms that cannot find local auditors within 70 miles. In order to isolate noise and focus on those economically meaningful cases, we retest our results based on two further refinements. First, we delete those firms that cannot find Big 4 auditors within 35 miles. We lose about 400 firms and our sample reduces to 3,228 observations. This will give us a relatively homogeneous sample. Nest, we create two dummy variables that only target those economically meaningful cases. The first one takes the value of 1 if a firm hires a Big 4 office that is located at least 50 miles farther than the closest Big 4 office and 0 otherwise. The second dummy variable takes the value of 1 if a firm hires a Big 4 office that is located at least 100 miles farther than the closest Big 4 office and 0 otherwise. Results are reported in Table 7.

Table 7. Does competitive audit fee affect office choice

\begin{tabular}{|c|c|c|c|c|c|c|c|}
\hline \multirow{3}{*}{$\begin{array}{l}\text { Independent } \\
\text { Variables }\end{array}$} & \multirow{3}{*}{$\begin{array}{c}\text { Predicted } \\
\text { Sign }\end{array}$} & \multicolumn{6}{|c|}{ Dependent Variable $=$ Distance Dummies } \\
\hline & & \multicolumn{2}{|c|}{ Distance-Closest $>50=1$ ) } & \multicolumn{2}{|c|}{ Distance-Closest $>100=1$} & \multicolumn{2}{|c|}{ Avoid Office from the Same Auditor $=1$} \\
\hline & & Coefficient & z-value & Coefficient & z-value & Coefficient & z-value \\
\hline ABSACCR & + & 1.225 & 1.03 & 0.757 & 0.58 & -2.017 & -1.27 \\
\hline DISCON & + & $0.535^{* *}$ & 2.4 & $0.44^{*}$ & 1.78 & -0.131 & -0.43 \\
\hline RESTATE & + & 0.135 & 0.68 & 0.001 & 0.01 & -0.426 & -1.48 \\
\hline AUDIT & - & $-0.054 * *$ & -1.97 & -0.038 & -1.22 & $-0.058 *$ & -1.87 \\
\hline OPSEG & + & -0.024 & -0.16 & -0.032 & -0.19 & -0.03 & -0.19 \\
\hline GESEG & + & $0.088^{* *}$ & 1.98 & $0.085^{*}$ & 1.84 & -0.049 & -0.72 \\
\hline NSPECIALIST & + & -0.195 & -1.09 & -0.151 & -0.78 & -0.151 & -0.75 \\
\hline CSPECIALIST & + & 0.204 & 1.14 & 0.181 & 0.93 & -0.305 & -1.53 \\
\hline SIZE & $?$ & 0.044 & 0.66 & -0.017 & -0.25 & 0.039 & 0.6 \\
\hline
\end{tabular}




\begin{tabular}{|c|c|c|c|c|c|c|c|}
\hline CYCLE & $?$ & $-0.272 * * *$ & -3.03 & $-0.265^{* * *}$ & -2.79 & -0.135 & -1.19 \\
\hline CAPITAL & $?$ & -0.445 & -1.45 & -0.281 & -0.86 & -0.407 & -1.06 \\
\hline ISSUE & $?$ & $-0.614 * *$ & -2.31 & $-0.639 * *$ & -2.25 & $-0.944 * * *$ & -3.03 \\
\hline CFO & $?$ & $0.417 * *$ & 2.05 & $0.511 * *$ & 2.26 & 0.045 & 0.2 \\
\hline QUICK & $?$ & -0.779 & -1.31 & -0.873 & -1.34 & -0.163 & -0.25 \\
\hline EMPLOYEE & ? & -3.175 & -0.95 & -1.78 & -0.67 & -2.567 & -1.44 \\
\hline TURNOVER & $?$ & -0.111 & -0.71 & -0.092 & -0.56 & -0.02 & -0.12 \\
\hline FOREIGN & $?$ & -0.138 & -0.63 & -0.131 & -0.53 & 0.185 & 0.79 \\
\hline$R \& D$ & $?$ & -0.207 & -0.28 & -0.749 & -0.76 & -1.563 & -1.36 \\
\hline ZSCORE & $?$ & 0.069 & 0.88 & 0.025 & 0.3 & -0.053 & -0.55 \\
\hline STDREV & $?$ & -0.526 & -0.99 & -0.363 & -0.78 & 0.076 & 0.11 \\
\hline CHREC & $?$ & $1.909^{*}$ & 1.72 & $2.45^{* *}$ & 2.09 & $2.648^{* *}$ & 2.15 \\
\hline CHEARN & $?$ & -0.649 & -1.56 & $-0.791 *$ & -1.81 & 0.261 & 0.55 \\
\hline State Dummies & & & YES & & YES & & YES \\
\hline \multicolumn{8}{|l|}{ Industry } \\
\hline Dummies & & & YES & & YES & & YES \\
\hline \multicolumn{8}{|l|}{ Number of } \\
\hline Observations & & & 2,836 & & 2,778 & & 2,264 \\
\hline Wald Chi2 & & & 287 & & 245 & & 168 \\
\hline \multicolumn{8}{|l|}{ Pseudo } \\
\hline R-Square & & & 0.14 & & 0.13 & & 0.12 \\
\hline
\end{tabular}

This table reports the results of probit model estimates with robust standard errors to correct for heteroscedasticity. Two-digit SIC industry dummies and state dummies are included to control for industry and state fixed effects and are not reported for brevity. The dependent variable in the first regression is a dummy variable that takes the value of one if a firm chooses a remote office that is more than 50 miles farther than the closest Big 4 office and zero otherwise. The dependent variable in the second regression is a dummy variable that takes the value of one if a firm chooses a remote office that is more than 100 miles farther than the closest Big 4 office and zero otherwise. The dependent variable in the third regression is a dummy variable that takes the value of one if a firm chooses a remote office but that office is from the same Big 4 accounting firm as the closest office and zero otherwise. ABSACCR is the absolute value of the performance adjusted abnormal accruals. DISCON is a dummy variable that takes the value of one if a firm reports small positive earnings and zero otherwise. RESTATE is a dummy variable that takes the value of one if a firm restated its financial statements and zero otherwise. AUDIT is the log-transformed audit fees. OPSEG is the number of operating segments, and GESEG is the number of geographic segments. NSPECIALIST is a dummy variable that takes the value of one if an auditor is the number one auditor in an industry in terms of aggregated audit fees in a specific fiscal year and zero otherwise. CSPECIALIST is a dummy variable that takes the value of one if an office is the number one auditor in terms of aggregated client audit fees in an industry within that city in a specific fiscal year and zero otherwise. SIZE is the natural log of total assets. CYCLE is a firm's operating cycle which is calculated as the sum of days' inventory and days' accounts receivable divided by 30, where days' inventory is calculated as 365 times the average of the beginning and ending inventory divided by the cost of goods sold, and days' accounts receivable is calculated as 365 times the average of the beginning and ending accounts receivable divided by sales. CAPITAL is the measure of capital intensity which is the ratio of gross property, plant, and equipment to total assets. ISSUE is the proxy of new issue of securities which is a dummy variable that takes the value of one if a firm issues equity or debt securities during the year and zero otherwise. CFO is defined as the difference between net income and total accruals, while total accruals are derived from the balance sheet accounts. QUICK is quick ratio which is defined as the ratio of the sum of cash and marketable securities to total assets. EMPLOYEE is the number of employees in millions. TURNOVER is asset turnover which is the ratio of sales to total assets. FOREIGN is a dummy variable that takes the value of one if a firm reports foreign sales and zero otherwise. $R \& D$ is the measure of R\&D intensity which is defined as the total R\&D expense deflated by total assets. ZSCORE is the Altman Z-score. STDREV is the standard deviation of revenues. We use a rolling window up to 10 years to estimate the standard deviation revenues. CHREC is change in receivables and CHEARN is change in net income. Both of these two measures are deflated by total assets. 
About 7\% of firms hire Big 4 offices at least 50 miles farther than the closest offices even though these local offices are located within 35 miles and about $6 \%$ of firms hire Big 4 offices at least 100 miles farther than the closest offices. Consistent with results reported earlier, the first regression in Table 7 shows that the coefficient of DISCON is positively correlated with remote auditor and significant at 5\% level. The coefficient of audit fee is negatively correlated with remote auditor and significant at 5\% level. Finally, the coefficient of the number of segments is positively correlated with remote auditor and significant at 5\% level. Results for the control variables are also similar to those reported earlier. Operating cycle is negatively correlated with remote auditor and significant at $1 \%$ level. The new issue of securities is negatively correlated with distance auditor and significant at $5 \%$ level. The net cash flow from operating activities is positively correlated with remote auditor and significant at $5 \%$ level, and accounts receivable growth is positively correlate with remote auditor and significant at $10 \%$ level. Results in the second regression are similar to those in the first regression. However, audit fee becomes insignificant, indicating that competitive pricing only happens within certain distance and remote auditors cannot offer more competitive price once they are located more than 150 miles away.

Finally, we are puzzled by the fact that some firms hire a remote office even though that office is from the same accounting firm as the local office. In order to test the determinants, we create a dummy variable that takes the value of 1 if a firm hire a remote office that is from the same accounting firm as the closest local office and 0 otherwise. Results are reported in the third regression in Table 7. About $4.6 \%$ of firms hire remote auditors even though they could hire the same Big 4 auditor within 35 miles. Few variables are significant. The only testing variable significant is audit fee, which is negatively significant at $10 \%$, indicating that firms avoid the closest office from the same accounting firms because the remote office offers more competitive audit price.

\section{Discussion and Conclusion}

We have documented two facts in this paper: First, we estimate the driving distance from firms' corporate headquarters to their lead Big 4 auditor offices. Even though prior studies have examined the distance between clients' headquarters and their auditors' offices, these studies do not separately examine this measure for clients audited by Big 4 auditors. As studies argue that Big 4 clients are fundamentally different from non-Big 4 clients, it is justified to devote a separate study to only Big 4 clients. Furthermore, the distance measures documented in prior studies are not precise due to estimation methods and data restrictions. These studies generally separate local from non-local auditors through dummy variables, but cannot precisely measure the distance, especially for firms that hire local auditors. Our study fills this gap and precisely documents the distance between Big 4 auditors and their clients. Second, we document the distance from a firm's headquarter to the closest Big 4 auditor office. This measure is important because it tells us how Big 4 auditor offices are located relative to their potential clients. It may also help us understand the national audit market and the competitions among accounting firms.

Both Jensen et al. (2008) and Choi et al. (2012) argue that distance affects audit quality and local auditors provide higher quality audit. But the causality could be the other way around, i.e. clients with higher quality earnings are more likely to choose a local auditor. Even if distance does reduce audit quality as these studies have argued, it still begs the question why some firms would choose remote auditors. Our study addresses this question and fills a gap in the audit literature. We show that firms that are more likely to manage earnings tend to hire remote auditors. We further show that the severity of earnings management increases with distance. The likelihood of financial restatements is higher among firms that hire auditors located more than 500 miles away, but not among firms that hire remote auditors less than 500 miles away. We also show that offering competitive audit price is only possible within certain distance. Beyond certain limit, audit fees are not correlated with distance.

Our results have raised a number of important questions that have not been addressed by the existing literature. First, why geographical proximity is so important in the auditor-client relationship? We provide two possible explanations. However, whether these explanations are valid is still an empirical question. Second, why Big 4 auditors are located so close to their potential clients if $71 \%$ of firms do not hire the closest auditor? Prior study has documented that the number of public clients audited by each Big 4 offices varies from a few to a few hundred (Francis et al., 2012). From an economic perspective, consolidating some small offices may reduce operating costs and provide scale of economy. However, it is not clear why Big 4 auditors still keep those small offices. Whether and how auditors balance the distance and the number of clients in each office is unknown.

\section{References}

Abbott, L.J., \& Parker, S. (2000). Auditor selection and audit committee characteristics. Auditing: A Journal of Practice \& Theory, 19, 47. 
Agarwal, S., \& Hauswald, R. (2010). Distance and private information in lending. The Review of Financial Studies, 23, 2757-2788.

Altman, E.I. (1968). Financial ratios, discriminant analysis and the prediction of corporate bankruptcy. The Journal of Finance, 23, 589-609.

Ayers, B.C., Ramalingegowda, S., \& Eric Yeung, P. (2011). Hometown advantage: The effects of monitoring institution location on financial reporting discretion. Journal of Accounting \& Economics, 52, 41-61.

Bae, K.-H., Stulz, R.M., \& Tan, H. (2008). Do local analysts know more? A cross-country study of the performance of local analysts and foreign analysts. Journal of Financial Economics, 88, 581-606.

Becker, C.L., Defond, M.L., Jiambalvo, J., \& Subramanyam, K.R. (1998). The effect of audit quality on earnings management. Contemporary Accounting Research, 15, 1-24.

Bell, T.B., Doogar, R., \& Solomon, I. (2008). Audit labor usage and fees under business risk auditing. Journal of Accounting Research, 46, 729-760.

Brown, J.R., Ivković, Z., Smith, P.A., \& Weisbenner, S. (2008). Neighbors matter: Causal community effects and stock market participation. The Journal of Finance, 63, 1509-1531.

Burgstahler, D., \& Dichev, I. (1997). Earnings management to avoid earnings decreases and losses. Journal of Accounting \& Economics, 24, 99.

Chaney, P.K., Jeter, D.C., \& Shivakumar, L. (2004). Self-selection of auditors and audit pricing in private firms. The Accounting Review, 79, 51-72.

Choi, J.-H., Kim, J.-B., Qiu, A., \& Zang, Y. (2012). Geographic proximity between auditor and client: How does it impact audit quality? Auditing: A Journal of Practice \& Theory, (Forthcoming).

Choi, J.-H., \& Wong, T.J. (2007). Auditors' governance functions and legal environments: An international investigation. Contemporary Accounting Research, 24, 13-46.

Copley, P.A., \& Douthett, E.B. (2002). The association between auditor choice, ownership retained, and earnings disclosure by firms making initial public offerings. Contemporary Accounting Research, 19, 49-75.

Copley, P.A., Gaver, J.J., \& Gaver, K.M. (1995). Simultaneous estimation of the supply and demand of differentiated audits: Evidence from the municipal audit market. Journal of Accounting Research, 33, 137-155.

Coval, J.D., \& Moskowitz, T.J. (1999). Home bias at home: Local equity preference in domestic portfolios. The Journal of Finance, 54, 2045-2073.

Coval, J.D., \& Moskowitz, T.J. (2001). The geography of investment: Informed trading and asset prices. Journal of Political Economy, 109, 811-841.

Dahlquist, M., Pinkowitz, L., Stulz, R.M., \& Williamson, R. (2003). Corporate governance and the home bias. The Journal of Financial and Quantitative Analysis, 38, 87-110.

DeAngelo, L.E. (1981). Auditor independence, 'low balling', and disclosure regulation. Journal of Accounting \& Economics, 3, 113-127.

DeAngelo, L.E. (1982). Mandated successful efforts and auditor choice. Journal of Accounting \& Economics, 4, 171-203.

Dechow, P.M., Sloan, R.G., \& Sweeney, A.P. (1995). Detecting earnings management. The Accounting Review, 70, 193-225.

DeFond, M.L. (1992). The association between changes in client firm agency costs and auditor switching. Auditing: A Journal of Practice \& Theory, 11, 16-31.

DeFond, M.L., Francis, J.R., \& Hu, X. (2008). The geography of auditor independence and SEC enforcement. Working Paper. University of Southern California, University of Missouri, and University of Oregon.

DeGeorge, F., Patel, J., \& Zeckhauser, R. (1999). Earnings management to exceed thresholds. Journal of Business, 72, 1-33.

Firth, M., \& Smith, A. (1992). Selection of auditor firms by companies in the new issue market. Applied Economics, 24, 247.

Fortin, S., \& Pittman, J.A. (2007). The role of auditor choice in debt pricing in private firms. Contemporary 
Accounting Research, 24, 859-896.

Francis, J.R., \& Krishnan, J. (2002). Evidence on accounting firm risk-management stategies before and after the private securities litigation reform act of 1995. Asia-Pacific Journal of Accounting and Economics, 9(2), 135-157.

Francis, J.R., Maydew, E.L., \& Sparks, H.C. (1999). The role of big 6 auditors in the credible reporting of accruals. Auditing: A Journal of Practice \& Theory, 18, 17.

Francis, J.R., Michas, P.N., \& Yu, M.D. (2012). Office size of big 4 auditors and client restatements. Working Paper. University of MIssouri-Columbia, University of Arizona, and Washington State University.

Francis, J.R., Reichelt, K., \& Wang, D. (2005). The pricing of national and city-specific reputations for industry expertise in the U.S. Audit market. The Accounting Review, 80, 113-136.

Francis, J.R., \& Wilson, E.R. (1988). Auditor changes: A joint test of theories relating to agency costs and auditor differentiation. The Accounting Review, 63, 663-682.

Francis, J.R., \& Yu, M.D. (2009). Big 4 office size and audit quality. Accounting Review, 84, 1521-1552.

French, K.R., \& Poterba, J.M. (1991). Investor diversification and international equity markets. American Economic Review, 81, 222.

Gaspar, J.-M., \& Massa, M. (2007). Local ownership as private information: Evidence on the monitoring-liquidity trade-off. Journal of Financial Economics, 83, 751-792.

Godfrey, J.M., \& Hamilton, J. (2005). The impact of R\&D intensity on demand for specialist auditor services. Contemporary Accounting Research, 22, 55-93.

Gould, W., Pitblado, J., \& Sribney, W. (2006). Maximum likelihood estimation with stata (3rd ed.). Stata Press.

Grinblatt, M., \& Keloharju, M. (2001). How distance, language, and culture influence stockholdings and trades. The Journal of Finance, 56, 1053-1073.

Guedhami, O., Pittman, J.A., \& Saffar, W. (2009). Auditor choice in privatized firms: Empirical evidence on the role of state and foreign owners. Journal of Accounting \& Economics, 48, 151-171.

Hau, H. (2001). Location matters: An examination of trading profits. The Journal of Finance, 56, 1959-1983.

Heath, C., \& Tversky, A. (1991). Preference and belief: Ambiguity and competence in choice under uncertainty. Journal of Risk \& Uncertainty, 4, 5-28.

Hou, K., \& Moskowitz, T.J. (2005). Market frictions, price delay, and the cross-section of expected returns. The Review of Financial Studies, 18, 981-1020.

Hribar, P., \& Nichols, D.C. (2007). The use of unsigned earnings quality measures in tests of earnings management. Journal of Accounting Research, 45, 1017-1053.

Ireland, J.C., \& Lennox, C.S. (2002). The large audit firm fee premium: A case of selectivity bias? Journal of Accounting, Auditing \& Finance, 17, 73-91.

Ivković, Z., \& Weisbenner, S. (2005). Local does as local is: Information content of the geography of individual investors' common stock investments. The Journal of Finance, 60, 267-306.

Ivković, Z., \& Weisbenner, S. (2007). Information diffusion effects in individual investors' common stock purchases: Covet thy neighbors' investment choices. The Review of Financial Studies, 20, 1327-1357.

Jensen, K.L., Kim, J.-M., \& Yi, H. (2008). The geography of U.S. Auditors. Working Paper. University of Oklahoma, The State University of New Jersey, and Korea University.

John, K., Knyazeva, A., \& Knyazeva, D. (2011). Does geography matter? Firm location and corporate payout policy. Journal of Financial Economics, 101, 533-551.

Johnson, W.B., \& Lys, T. (1990). The market for audit services. Journal of Accounting \& Economics, 12, 281-308.

Johnstone, K.M., \& Bedard, J.C. 2003). Risk management in client acceptance decisions. The Accounting Review, 78, 1003-1025.

Johnstone, K.M., Li, C., \& Luo, S. (2011). Client supply chain relationships, audit firm selection, and implications for audit quality and pricing. Working Paper. University of Wisconsin, University of Pittsburgh, and National University of Singapore. 
Jones, J.J. (1991). Earnings management during import relief investigations. Journal of Accounting Research, 29, 193-228.

Kang, J.-K., \& Kim, J.-M. (2008). The geography of block acquisitions. The Journal of Finance, 63, $2817-2858$.

Kedia, S., \& Rajgopal, S. (2009). Neighborhood matters: The impact of location on broad based stock option plans. Journal of Financial Economics, 92, 109-127.

Kedia, S., \& Rajgopal, S. (2011). Do the SEC's enforcement preferences affect corporate misconduct? Journal of Accounting \& Economics, 51, 259-278.

Kinney, W.R., Jr., Palmrose, Z.-V., \& Scholz, S. (2004). Auditor independence, non-audit services, and restatements: Was the U.S. Government right? Journal of Accounting Research, 42, 561-588.

Kothari, S.P., Leone, A.J., \& Wasley, C.E. (2005). Performance matched discretionary accrual measures. Journal of Accounting \& Economics, 39, 163-197.

Lennox, C. (2005a). Audit quality and executive officers' affiliations with CPA firms. Journal of Accounting \& Economics, 39, 201-231.

Lennox, C. (2005b). Management ownership and audit firm size. Contemporary Accounting Research, 22, $205-227$.

Lerner, J. (1995). Venture capitalists and the oversight of private firms. The Journal of Finance, 50, $301-318$.

Loughran, T., \& Schultz, P. (2005). Liquidity: Urban versus rural firms. Journal of Financial Economics, 78, 341-374.

Malloy, C.J. (2005). The geography of equity analysis. The Journal of Finance, 60, 719-755.

Menon, K., \& Williams, D.D. (2004). Former audit partners and abnormal accruals. The Accounting Review, 79, 1095-1118.

Merton, R.C. (1987). A simple model of capital market equilibrium with incomplete information. The Journal of Finance, 42, 483-510.

Mian, A. (2006). Distance constraints: The limits of foreign lending in poor economies. The Journal of Finance, 61, 1465-1505.

Palmrose, Z.-V., Richardson, V.J., \& Scholz, S. (2004). Determinants of market reactions to restatement announcements. Journal of Accounting \& Economics, 37, 59.

Petersen, M.A., \& Rajan, R.G. (2002). Does distance still matter? The information revolution in small business lending. The Journal of Finance, 57, 2533-2570.

Pirinsky, C., \& Wang, Q. (2006). Does corporate headquarters location matter for stock returns? The Journal of Finance, 61, 1991-2015.

Reynolds, J.K., \& Francis, J.R. (2000). Does size matter? The influence of large clients on office-level auditor reporting decisions. Journal of Accounting \& Economics, 30, 375-400.

Shu, S.Z. (2000). Auditor resignations: Clientele effects and legal liability. Journal of Accounting \& Economics, 29, 173-205.

Simon, D.T., \& Francis, J.R. (1988). The effects of auditor change on audit fees: Tests of price cutting and price recovery. The Accounting Review, 63, 255-269.

Simunic, D., \& Stein, M. (1987). Product differentiation in auditing: Auditor choice in the market for unseasoned new issues. Canadian Certified General Accountants Research Foundation. Vancouver, B.C.

Teo, M. (2009). The geography of hedge funds. The Review of Financial Studies, 22, 3531-3561.

Wang, Q., Wong, T.J., \& Xia, L. (2008). State ownership, the institutional environment, and auditor choice: Evidence from China. Journal of Accounting \& Economics, 46, 112-134.

Weber, J., \& Willenborg, M. (2003). Do expert informational intermediaries add value? Evidence from auditors in microcap ipos. Journal of Accounting Research, 41, 681-720.

White, H. (1980). A heteroskedasticity-consistent covariance matrix estimator and a direct test for heteroskedasticity. Econometrica, 48, 817-838. 


\section{Notes}

Note 1. Throughout this paper, we refer to the forty-nine jurisdictions in the US, the forty-eight states (Hawaii and Alaska are excluded) plus the District of Columbia, as states.

Note 2. Apparently, under these methods, when a client's headquarter and its auditor's office are in the same city, the distance is estimated as zero. As our findings show that the majority of the firms and their auditors are located within 33 miles, most likely in the same city, these methods will inevitably estimate distance with big errors and noise.

Note 3. For this line of literature, please see DeAngelo (1982), Francis and Wilson (1988), Johnson and Lys (1990), DeFond (1992), and Firth and Smith (1992).

Note 4. Since French and Poterba (1991), a growing body of literature has been examining the importance of geographic distance in economics. For other studies, please see Grinblatt and Keloharju (2001), Hau (2001), Dahlquist et al. (2003), Mian (2006), Bae et al. (2008), and Teo (2009).

Note 5. Following Jones (1991) and Kothari et al. (2005), we use the ordinary least squares (OLS) to estimate the following performance-adjusted Jones model for the full COMPUSTAT sample by fiscal year and two-digit industry SIC code (with a minimum of 10 observations required for an industry to be included in a year), and controlling for concurrent firm performance with NI: TA $=\alpha+\beta_{1} \Delta \mathrm{REV}+\beta_{2} \mathrm{PPE}+\beta_{3} \mathrm{NI}+\varepsilon$, where TA is total accruals; $\Delta \mathrm{REV}$ is revenues in year $t$ less revenues in year $t-1$; PPE is gross property, plant, and equipment; and NI is operating income after depreciation. All variables are deflated by lagged total assets. The absolute value of residuals from the above equation is used to measure discretionary accruals.

Note 6. According to COMPUSTAT, there are 4 segment types: business segment, operating segment, geographic segment, and state segment. Business segments are organized by product lines or divisions. Operating segment will combine either country, state, or region along with business segments. Geographic segment presents the data by geographic locations, and state segment reports the information by US geographic information (some firms use region, some use city, and some use state). The key issue is that these categories are not comparable. Some companies use geographic segments and some use operating segments, and in most cases, a firm might use geographic segments and operating segments/business segments in the same year. As few firms report information on business and state segments, we only construct two variables based on the operating and geographic segments, and we code missing values as 1 .

Note 7. We also include financial distress (LOSS), Leverage (DEBT), and return on assets (ROA). LOSS is a dummy variable that takes the value of 1 if net income is negative and 0 otherwise. Leverage (DEBT) is the ratio of long-term debt to total assets. Return on assets (ROA) is the ratio of net income to total assets. As these variables are insignificant in the multiple regressions, results are not reported.

Note 8 . We use the following equation to calculate this measure: $0.717 *$ working capital/total assets $+0.847 *$ retained earnings/total assets $+3.107 *$ earnings before interest and taxes/total assets $+0.42 *$ book value of equity/total liabilities $+0.998 *$ sales/total assets.

Note 9. We also include the ratio of accounts receivable to total assets, the ratio of total inventory to total assets, standard deviation of cash flows, standard deviation of net income, change in revenues, change in inventory, and change in the number of employees as additional controls. As these variables are insignificant in the multivariate regressions, results are not tabulated.

Note 10. COMPUSTAT only provides a company's current headquarter location, but does not have information about historical headquarter location. We downloaded this dataset early in 2007 when the 2005 fiscal year financial information was available through COMPUSTAT.

Note 11. After we merge the Audit Analytics sample with COMPUSTAT's name and address file, there are 6,924 observations, including both Big 4 and Non-Big 4 clients with headquarter street address information.

Note 12 . There are only 14 companies headquartered in these two states in the sample, and none of them engages out-of-state auditors.

Note 13. Estimating errors arise from two sources. First, it comes from firms' street address. Some firms don't use street address, and cannot be located through Google map. For example, Applied Industrial Technologies uses 1 Applied Plaza as its address. Through the description on the company's website (http://www.applied.com/site.cfm/contact.cfm), it seems that the company is located on Euclid Avenue. Some companies use street address, but Google does not recognize these addresses. For example, Commonwealth Telephone Enterprises' address is listed as 100 CTE Drive, Dallas, PA 18612, but Google map does not have this 
address. We could either drop this address, or as an alternative, using another street address (758 Tunkhannock Hwy) about 300 feet away to replace this address. Ford Motor Company's address is One American Road, Dearborn, Michigan 48126, but we couldn't find this address in Google map. Sometimes, Google recognizes an address, but will not show the driving direction unless you put the company's name before that street address. For example, Grainger Inc's address is 100 Grainger Parkway, Lake Forest, IL, but if you just type the street address, it won't give you the driving direction. You have to type "Grainger 100 Grainger Parkway" or "W W Grainger Inc 100 Grainger Parkway". When a company's zip code is incorrect, Google sometimes will correct the error (not always). Sometimes, a company's reported zip code cannot be found in Google map, which will automatically change to another nearby zip code. For example, Pepco Holdings' street address is 701 Ninth St NW, Washington, DC 20068. Google will automatically use 20001 instead of 20068, but the distance between 20068 and 20001 is only 1.1 miles. There are also some problems in Google Map. Sometimes Google does not recognize full address but abbreviated ones. For example, A.O. Smith Corporation's address is 11270 West Park Place, Milwaukee, WI 53224. But if you type in this address, it will direct you to $11270 \mathrm{~W}$ Park Rd, Blue Springs, MO 64015. You have to type "11270 W Park Pl" to get the right direction. Google also does not recognize One Williams Center, 74172. Instead, Google's record is One Williams Center, Tulsa, OK 74103.

Note 14. The number of unique Big 4 offices identified in this study is fairly large compared to other studies. Francis and $\mathrm{Yu}$ (2009) have identified 285 unique Big 4 offices, and the sample in DeFond et al. (2008) consists of 245 unique Big 4 offices.

Note 15. A number of different methods have been used by the literature to measure distance. The most popular method is the Haversine formula which employs the latitude and longitude data from the US Census Bureau to measure distance (Coval and Moskowitz, 1999 and 2001; Malloy, 2005; Gaspar and Massa, 2007; Ivkovic and Weisbenner, 2007; Kang and Kim, 2008; Kedia and Rajgopal, 2011; Johnstone et al., 2011). Some studies use the Metropolitan Statistical Area (MSA) as the geographical unit of analysis (Pirinsky and Wang, 2006; Brown et al., 2008; Kedia and Rajgopal, 2009). A few studies also measure the distances from a firm's headquarter to major metropolitan areas, and the distance to the nearest airport (Loughran and Schultz, 2005; Hou and Moskowitz, 2005; John et al., 2011).

Note 16. Estimates using the Haversine formula are accurate to around $0.3 \%$, while estimates using the Vincenty formula are accurate to within $0.5 \mathrm{~mm}$.

Note 17. This process has created a large dataset that has $1,234,596$ observations. It takes about 20 days to estimate this dataset through Google Map.

Note 18. In order to verify the reliability of this sample, we manually verify street addresses and auditor locations on $10-\mathrm{K}$ filings for all companies that hire auditors more than 300 miles away from their corporate headquarters. Whenever there are inconsistencies, we correct our sample based on their 10-K filings. About 13\% of these firms' street addresses or auditor locations are inconsistent with the records in our sample. However, we believe errors in the sample would work against finding the predicted results.

Note 19. We also include other variables, including foreign sales, book to market ratio, financial restatement, audit fees, auditor specialists. As these variables are insignificant, we have dropped them when reporting the final results. Consistent with Becker et al. (1998), Menon and Williams (2004), Dechow et al. (1995), and Hribar and Nichols (2007), we find that the absolute value of discretionary accruals is negatively correlated with firm size (SIZE) and net operating cash flows (CFO), and positively correlated with sales growth (CHSALE) and the standard deviation of net operating cash flows (STDCFO). Consistent with Reynolds and Francis (2000), we find that the absolute value of discretionary accruals is negatively correlated with Altman z-score (ZSCORE). We also find that inventory level (INVENTORY), quick ratio (QUICK), assets turnover (TURNOVER), and accounts receivable growth (CHREC) are all positively correlated with the dependent variable. However, debt ratio (DEBT), return on assets (ROA), and the loss dummy (LOSS) are not correlated with the dependent variable. For brevity, these results are not tabulated.

Note 20. The reason why these coefficients are so big is because the estimated discretionary accruals are close to zero. The mean of the performance-based discretionary accruals is about 0.00006 .

Note 21. Because of so many dummy variables in the regressions, some of the observations are dropped during the estimation process, and that is why the number of observations for each regression reported on Table 6 is less than 3,588 . 